\title{
Adaptation of loanwords of the suffix type *-eTA in Finnish and Saami
}

This article concerns loanwords that have been adapted to the adjective suffix type ${ }^{\star}-e T A$ in Finnish $(-e A)$ and North Saami $(-a t)$. The questions to answer are: From which languages the loanwords have been borrowed and adapted to this adjective type? Which processes have been used to adapt loanwords to the suffix type ${ }^{\star}-e T A$ ? Can we say something about the productivity of a suffix by studying the loanwords it has adapted? According to the data, the loanwords have been gained especially from Germanic and Scandinavian languages. Also, the North Saami and Finnish do not have common loanwords. They have borrowed words from same source but separately, i. e. they cannot be recontstructed to common Finno-Saamic form. However, both languages have used the same methods in adapting loanwords to the suffix type ${ }^{*}-e T A$. Both Finnish and North Saami has also young loanwords in suffix type ${ }^{*}-e T A$ which indicates that the suffix has been productive enough to adapt loanwords perhaps longer than thought. It is likely that the Finnish $-e A$ adjectives would be even now adapted to -at in North Saami.

1. Introduction

1.1. Loanword adaptation

1.2. The study of loanwords

in Finno-Ugric studies

1.3. The aim of this study

2. Borrowing

2.1. What tends to be borrowed?

2.2. Layers of loanwords

3. Development of the suffix ${ }^{*}-e T A$

3.1. The development and function of the suffix * ${ }^{*}$ TA

3.2. Derivative or stem type?

3.3. Productivity

3.4. Finnic ${ }^{*}-e \delta A$

3.5. Saami ${ }^{*}$-ette
4. Processes of assigning loanwords containing ${ }^{\star}-(e) T A$

4.1. Derivation

4.1.1. Regular derivation

4.1.2. Other derivations

4.2. Morphological adaptation

4.2.1. Morphophonological

adaptation

4.2.2. Etymological nativization

4.2.3. Analogical adaptation

4.3. Affixation

5. Conclusions

5.1. Semantics of the loanwords

5.2. The age and type of loanwords

5.3. The productivity of ${ }^{\star}-e T A$ 


\section{Introduction}

\section{I.I. Loanword adaptation}

All languages have loanwords. Loanwords tend to require adaptation in order to be usable in the recipient language (Haspelmath 2009: 42). Languages with gender and inflection need to assign words to a gender and inflection class in order to be able to use the words in syntactic patterns that require gender agreement or inflection (ibid.). There are many different methods, even within a single language, through which loanwords are adapted to the language system.

Loanwords tend to undergo changes that make them fit better with both the phonological and morphological systems of the recipient language. These changes are called loanword adaptation. (Haspelmath 2009: 42.) Another term is nativization, as used by Hock and Joseph (1996: 262):

Many languages nativize foreign borrowings to make them conform to native restrictions on word or syllable structure.

The adaptation may be purely phonological. In Finnish, for example, word-initial consonant clusters have been simplified because Finnish does not have consonant clusters in its native phonological system, e. g. Finnish takki 'jacket, coat' < Old Swedish stakker 'a shirt-like garment' (SSA 3: 259). It can be also morphological: languages with inflection, such as Finnish and Saami, need to adapt loanwords in order to make them usable, e. g. when they are employed as parts of syntactic units that require inflection. The adaptation methods depend on the word class to which the loanword is assigned, the source and form of the loanword, and, perhaps, whether or not the donor language and the recipient language are related. For example, nouns borrowed into Finnish do not require much adaptation, e. g. Eng net > Fi netti 'Internet' (see e. g. Bentlin 2008: 266). Verbs, on the other hand, require some more adaptation in order to be used, e. g. Eng to skate > skeita-ta (inf.): skeittaa '(s/he) skates'. 
Adaptation of loanwords of the suffix type *-eTA in Finnish and Saami

\section{I.2. The study of loanwords in Finno-Ugric studies}

The history of loanword research regarding Finnish is long (e. g. Tunkelo 1913-1918). The focus of loanword studies in Finno-Ugric studies has been on sound correspondences and substitutions between the donor and recipient languages (see e.g. Koivulehto 1999; Sammallahti 1999). Some studies of loanword adaptation have been conducted, one even concerning *-eTA adjectives in Finnish by Terho Itkonen (1982), who has studied variation in words such as laaja, lavea 'wide'. Muusa Ojanen (1985) has studied the category of adjectives in language contact between Lude and Russian. She has noticed that Russian loan adjectives have been adapted to the domestic inflection type (Ojanen 1985: 283). Marko Pantermöller (2003) has studied the orthographical adaptation of new loanwords in Finnish. Osmo Nikkilä $(1981 ; 1998)$ has turned his focus to suffixal variation, particularly in Finnish adjectives (including loanwords), and has tried to identify the mechanisms behind this variation. Vesa Jarva (2003) has continued this research and extended it to sound-symbolic vocabulary. He has studied the eastern dialects of Finnish and concentrated on possible Russian loanwords in their vocabularies. He has found that the word groups are not always simply loanwords or domestic formations. The border between loanwords and sound-symbolic formation is not clear due to folk etymology and cognitive association, which blur the distinction between polysemy and homonymy.

Loanword research regarding Saami has not been as crowded as that of Finnish, but its history is also long, dating back to the 19th century (e.g. Friis 1887; Qvigstad 1893). Modern loanword research has been mostly in the hands of Pekka Sammallahti (esp. 1998) and Ante Aikio (e.g. 2006; 2007). Aikio in particular has studied the loanword adaptation methods used in North Saami, and in this study, I have also used his term etymological nativization, which suggests that strong contacts and bilingualism between Finnish and Saami have significantly affected loanword adaptation in Saami.

\section{I.3. The aim of this study}

This article ${ }^{1}$ deals with the question of how else loanwords have been assigned to the adjective class, to the suffixal type ${ }^{*}-e T A$, in Finnish (PFS ${ }^{*}-e T A>\mathrm{Fi}-e A$, e. g. makea 'sweet') and Saami (PFS *-eTA $>\mathrm{SaaN}{ }^{*}$-at : -ada, modifier -es - e.g. njuolgat, gen.-acc. njuolgada, mod. njulges 'straight'). 
In Finnic and Saami languages this formation type includes both native words and loanwords. Traditionally, it has been considered that the Uralic suffixes were consonant-initial (Lehtisalo 1936: 2), and thus the adjective suffix has been reconstructed in the form ${ }^{*}$-TA in the Finno-Saamic protolanguage as well (Korhonen 1981: 322). However, in both Finnish and Saami, the suffix includes a vowel that can be reconstructed in the FinnoSaamic protolanguage as ${ }^{\star}-e$. It is possible that this vowel has separated from the stem to become part of the suffix (Lehtisalo 1936: 2), but because the vowels in the Saami and Finnic suffixes can be traced back to the same vowel, we may assume that the vowel was already part of the suffix in the Finno-Saamic protolanguage.

The category of ${ }^{*}-e T A$ adjectives in Finnish and North Saami includes loanwords that have been adapted to this adjective system. Most of the loanwords are so old that they have been fully adapted to the system and etymological research is needed in order to find out whether the word is a loanword or a native derivation. In the present paper, I have classified the loanwords based on the method by which they have been adopted into Finnish and Saami. The methods can be divided into different developmental processes: derivation, morphological adaptation ${ }^{2}$ and affixation. I have further divided the category of morphological adaptation into three separate subcategories: morphophonological adaptation, etymological nativization and analogical adaptation. These terms are discussed in greater detail in section 4. Derived words tend to be treated as native formations and have an existing, free stem, e. g. rust > rusty. Words formed through morphological adaptation and affixation look like derivations but lack a basic word, meaning they are bound-stem words, e. g. nasty is not derived from the form ${ }^{\star *}$ nast, although it has the same adjectival function as other $-y$ derivations, such as rusty or nouny. In Finnish studies, Alpo Räisänen (1978: 338) has noted that cognitive derivation is not only a process of adding suffixes to a stem. Suffixes never occur alone, and thus new words are more likely to be derived by using correlative patterns and model words.

After establishing the developmental paths through which the ${ }^{*}$-etA adjectives have developed in Finnish and North Saami, there are other issues to address: 
- Based on the data, is it possible to identify a golden age of ${ }^{\star}-e T A$ formations, e. g. by monitoring the age and direction of loanwords assigned to this suffix type in Finnish and Saami?

- If we have an adjective that is not formed through regular derivation, should we regard the word as a derivative? For example, the Finnish word makea 'sweet' does not have an underived stem, although a speaker can recognize it as an adjective due to the ending -ea. In other words, what is the relationship between regular derivation and other adaptation methods?

- The previous question is related to suffixal productivity: can a suffix be regarded as productive if it is employed in loanwords that are not actually formed by derivation but by morphological adaptation? If we understood the adaptation mechanisms better, we could perhaps study diachronic suffixal productivity in languages that do not have a long written history. According to Koivisto (2013: 237), productivity may concern a formal type (word form, model) as well as the suffix. Thus, we may view a word form as productive even when the derivations do not have free stems.

The data used for this study consists of ${ }^{*}-e T A$ adjectives in Finnish and Saami that have a loanword etymology or have been derived from a borrowed stem. The data has been collected from the following etymological dictionaries and databases: Álgu - the "Etymological database of the Saami Languages" (<http://kaino.kotus.fi/algu $>$ ) and Suomen sanojen alkuperä (1992-2000, later called SSA 1-3). In the contemporary languages, the productivity of this suffix is considered low or non-existent, and thus words formed with ${ }^{*}-e T A$ tend to be well presented in dictionaries. The Finnish data (ca. 180 words) has been collected from a traditional etymological dictionary whereas the North Saami data (ca. 110 words) is from an etymological database where the dependencies and relatedness are marked with arrows, not words. Most of the loanwords in this data have been borrowed into Proto-Finnic or Proto-Saami. The data presented here represents the most reliable loanwords in SSA. Some etymologies that have been suggested as loanword etymologies have been discarded in $\mathrm{SSA}^{3}$, although the explanation for these in SSA is "descriptive", which essentially means "unknown". I have not included such etymologies in this article, although the loanword etymologies may later prove valid. 


\section{Borrowing}

\section{I. What tends to be borrowed?}

Anything can be borrowed; not only words, but also morphological and syntactic structures. However, in order to assume structural borrowing one must find lexical borrowing. This is because words are the least resistant to borrowing, and loanwords may arise even in the case of rather scarce contacts, unlike morphological and syntactic structures, which demand intensive contacts between languages. Of vocabulary, nouns tend to be borrowed easily as they do not require much grammatical adaptation into the language. Due to the need for grammatical adaptation, verbs are more resistant to borrowing. (Haspelmath 2009: 35.) What about adjectives? Muusa Ojanen (1985: 40) refers to earlier loanword studies (e. g. Haugen 1953, Roos 1980, Lagman 1971), according to which adjectives are even more resistant to borrowing than verbs. However, Uri Tadmor (2009: 61) suggests that the borrowability of adjectives and verbs is around the same. According to Tadmor (ibid.), ca. 15\% of adjectives and adverbs is borrowed, while the figure for verbs is $14 \%$. The difference between Ojanen's and Tadmor's notions is that Ojanen presents results of sporadic languages such as Estonian and Norwegian, whereas Tadmor presents an average of 41 languages that represent different linguistic families (WOLD). The difference in borrowability of different word classes between languages is rather high, depending on the language systems, i. e. how much adaptation a word needs in order to fit the word class. The more adaptation the loanword needs, the less likely it is to be borrowed. In addition, the derivations of a borrowed stem are usually seen as domestic formations, and thus they tend to be left out of loanword statistics, not to mention that there are different ways of defining an adjective.

Any word can be borrowed, but some semantic fields are more borrowable than others. Language contacts are also cultural contacts, and usually a new cultural item comes with a word. Thus, we may make assumptions on e.g. where agriculture and herding has come to Finnic speakers. On the other hand, words denoting everyday life tend to be frequently used and thus well preserved (Häkkinen 1997: 176). Everyday words may also be borrowed, usually for reasons of prestige (Campbell 2004: 64-65). Thus, Finnic has borrowed the PFi word ${ }^{\star} k a k l a$ 'neck' (> Fi kaula, dial. kakla 'id.') from Baltic (SSA 1: 331) although it had a word of its own; PFi *sepä 
'neck' (SSA 3: 169). Campbell (2004: 65) also mentions derogatory borrowing. This is the opposite of prestige borrowing, meaning that borrowed words have a negative evaluation. Such an example from Finnish is koni 'old, bad horse', which is borrowed from Russian kon' 'horse' (Campbell 2004: 65; SSA 1: 396).

Loanwords in the World's languages: A Comparative Handbook (2009, later called WOLD) presents studies of loanwords in various languages. These languages are a selection from around the world, representing different language families (Swahili, Romanian, Kildin Saami, Lower Sorbian, British English, Old High German, etc.). The scholars had a list of denotations, consisting of ca. 1100 meanings (WOLD). Uri Tadmor (2009: 64) presents semantic fields and calculates the percentage of loanwords in each. He lists fields such as religion and belief, food and drink, cognition, time, quantity, the physical world, the body, spatial relations and sense perception. The semantic fields with the most loanwords are, unsurprisingly, religion and belief and clothing and grooming. Both are cultural areas and cultural words tend to be borrowed alongside new phenomena. The fields most resistant to borrowing are the body, spatial relations and sense perception. (ibid.)

The list in WOLD also includes ca. 120 adjectival denotations (adjectives treated as a semantic word class), such as 'black', 'bright', 'sweet', etc. The nine most resistant semantic adjectives belong to two semantic fields: sense perceptions (e. g. 'bright, 'loud', 'bitter', 'black') and spatial relations ('wide', 'right (side)', 'long'). The Finnish and North Saami ${ }^{\star}$-eTA adjectives also include loanwords from these denotations, although they should be the most resistant to borrowing (e.g. SaaN girkat 'bright (of eyes)' < Fi kirkas 'bright' and Fi lakea 'wide' < PScand ^flakja-). Even more loanwords can be seen if we look at all adjectives in Finnish and North Saami (e. g. Fi musta 'black' is a Germanic loanword, see Koivulehto 2001: 71; Rauhala 2011b: 276-278).

\subsection{Layers of loanwords}

One difficult issue in this study and with this type of morphological data is that suffixes tend to change over time. An earlier derivation may have disappeared or it may occur only in certain dialects or related languages. Sometimes a new suffix does not replace the old one. Instead, both continue to exist, causing variation that makes the word group appear fuzzy and confusing. Adjectives such as valkea and valkoinen both mean 'white', 
but the suffix -eA has been replaced with -inen, which is the default adjective suffix in contemporary Finnish. Another pattern is punainen 'red', punakka 'red (of skin)', and punerva 'reddish', all of which are derived from puna 'red (colour, substance)', a word which exists nowadays in Finnish mostly in compounds such as punaposki 'one who has red cheeks' (SSA 2: 427).

In studies of Indo-European languages, the vast variation in suffixes has been interpreted so that the etymon in the Indo-European protolanguage was an underived stem, and the suffixes were added later in the independent languages (Beekes 1995: 196). In Finno-Ugric languages, the need to add a suffix to mark adjectives can be seen especially in Saami, where the adjective system requires a marker indicating whether the adjective is a modifier or predicative. The marker has also been added to old Uralic adjectives, such as SaaN odas, mod. odda 'new', where the predicative form odas has the element $-s$ and the attribute form odta is the phonological cognate of Proto-Uralic *wude 'new' (Álgu, s. v. ođas).

Loanword studies help us to estimate the approximate time when a word has been borrowed. In derivative morphology, this means that a derivation cannot be made before the word has been borrowed. Loanwords are divided into layers depending on which language they come from. In dating these layers, we utilize knowledge of neighbouring languages and language contacts, as well as knowledge of language-internal phonological and morphological processes.

For the Finno-Saamic protolanguage, the main source for loanwords was Proto-Baltic (e. g. Fi halla 'frost', SaaN suoldni 'dew; haze, mist, steam, over water or on ground’ = PFS `̌̌alna < PBalt `šalnà, SSA 1: 133). At the same time and later on, Proto-Finno-Saamic and later Proto-Finnic, as well as Pre- and Proto-Saami, were under a strong Proto-Germanic influence (see map in Aikio 2006: 45). There are hundreds of words in Finnic for which a Proto-Germanic etymology has been suggested (see LÄGLOS 1-3).

Saami has had separate connections with Indo-European languages (Sammallahti 1999: 81-82; Koivulehto 1999: 211; Aikio 2006). Recently, Aikio (2006: 39) proposed that the contacts between Saami and Proto-Germanic were tighter and dated further back than assumed in previous studies. Aikio suggests that the Saami people had independent connections with Germanic peoples, whereas earlier it was assumed that the words from Proto-Germanic in Pre- and Proto-Saami would have spread mostly via Pre- and Proto-Finnic. The northward expansion of Proto-Saami has 
been dated to the Iron Age. Aikio (ibid.) dates the contacts with Proto-Germans to the Bronze Age, when the major sound changes in Proto-Saami had not yet emerged (the Pre-Saami phase). He assumes that Proto-Saami disintegrated during the Iron Age, around 0-500 AD.

Later on, the Finnic languages acquired words from the Slavic and Scandinavian directions, and loanwords were acquired from Low German as well (Thomsen 1869; Bentlin 2008). These contacts have lasted up until modern times, with recent loanwords coming from Swedish, Russian and, most recently, English. The Saami have had independent contacts with their neighbours the Norwegians, Swedes, Finns, Karelians and Russians. The contacts have left their mark on the contemporary languages.

North Saami has a total of ca. 110 -at adjectives, of which 34 are loanwords. Finnish has ca. $180-e A$ adjectives, of which only 17 are given a loanword etymology in SSA. The number of loanwords in the Finnish data is surprisingly low. The primary reason for this is the large number of unknown etymologies. The Finnish data consists quite largely of expressive words, i. e. words that either denote affective concepts or attach a positive or (more commonly) negative affect to a neutral concept (Aikio 2009: 26-27). Sound-symbolic words are words that formally describe their entity (ibid.). About half of the ${ }^{*}-e T A$-adjectives in Finnish are either of unknown origin or described as expressive, although expressive words may also be of loan origin.

\section{Development of the suffix *-eTA}

\section{I. The development and function of the suffix *-eTA}

The suffix *-eTA (< PFP *-(e)TA) still exists at least in Permic, Finnic and Saami (Uotila 1933), but cognates have also been suggested in Mordvin and Mari (Beke 1911: 129; Hallap 1983). The oldest words formed with the suffix *-eTA are Fi pimeä 'dark (of light)' (< PFP * pilmitä or *pilmetä 'id.', cognates in Komi pemid and Udmurt pejmit $\left.{ }^{4}\right)$, and pireä 'lively' (= Ko perid 'id.').

The assumption that adjectives were not a separate category in the Uralic (or Finno-Permic) protolanguage has created the need to assume some other earlier function than adjectival for the suffix ${ }^{*}-(e)$ TA. Hakulinen (1979: 121) suggests that the previous function would have been possessive, e. g. makea 'sweet' < 'thing that has taste in it'. Hakulinen's suggestion is possible, but as the suffix has no other function than adjectival in the 
present languages, it is not possible to reconstruct other functions for the protolanguages either.

There are some non-derived, common Uralic words that are semantically adjectives (e.g. PU ${ }^{\star} w u \delta^{\prime} e^{\prime}$ 'new' > Fi $u u s i$, SaaN odda 'id.') $)^{5}$ In addition, the suffix *-eTA has only an adjectival function in the languages in which it still most certainly exists (the Finnic, Saami and Permic languages). Thus, we may expect that there has been some system dividing adjectives from other classes, or at least there has been a need to mark adjectival function. Janhunen (1982: 28) claims that one cannot distinguish a subclass of adjectives in Proto-Uralic based on morphological criteria. Even though such derivational forms would not demonstrate the existence of a basic word class of adjectives (Post 2008: 350), they may indicate the importance of defining an adjectival meaning or function.

In the Finnic and Saami languages, the adjective system has changed much since the time of their common protolanguage. In both language groups, the modifier has undergone major changes. In the Finno-Saamic protolanguage, the modifier was presumably morphologically unmarked and did not agree with its head in number or case (Ravila 1960: 28; Pajunen 1998: 78). In Saami, adjectives have gained a grammatical function as the attribute form has become formally different from the nominative form. Finnic adjectives, on the other hand, have developed agreement both in number and case with their heads in attribute position.

The suffix ${ }^{*}$-eTA seems to have been a denominal adjective suffix (see Rauhala 2011a) that was added to nouns ending in ${ }^{*}-a$ and ${ }^{*}-i$, e. g. Finnish tahmea 'sticky' < tahma 'sticky substance', and North Saami čuovgat 'light (adj.)' < čuovga 'light (n.)', which probably dates back to Finno-Saamic *'soyi (Bergsland 1964: 144; Sammallahti 1998: 235). The loss of the phonological rule may be explained if we assume that the $-e$ in the suffix was reanalysed from being part of the root to being part of the suffix. Thus, it has been possible to make new adjectives by adding the bisyllabic suffix to the monosyllabic root and the last syllable has become irrelevant with regard to word formation.

\subsection{Derivative or stem type?}

The Uralic languages have a rich suffixal morphology. They are more agglutinative than fusional, although some, e. g. Estonian and North Saami, show more fusional features than others, mostly due to erosion in their morphol- 
ogy (cf. Laanest 1982). Word formation in Finnish also uses other methods than purely suffixal ones. Regarding Finnish word formation processes, Alpo Räisänen has identified four types of patterns: 1. derivation (Räisänen assumes that this may be a pattern that is not used at all by the average speaker), 2. correlational derivation (korrelaatiojohto), 3. model derivation (mallisanajohto), and 4. structure-internal derivation (vartalonsisäinen johto). The structure-internal derivation of colloquial Finnish -eA-adjectives may produce such words as pähee 'cool', sähee 'id.' ( $-e A>$ coll. $-e e)$, which are possibly formed by using the model of kähee 'coarse (of voice); cool'.

According to Räisänen, correlational derivation is based on derivational patterns, such as kala 'a fish', kalastaa 'to fish', kalastella 'to fish (freq.)', kalastelu 'fishing (freq.)'. This pattern has probably been a model for erä 'wilderness', ?erästää, erästellä 'to wander in wilderness; hunt, fish', erästely 'being in the wilderness'. The verb ${ }^{* *}$ erästää does not exist in SMS. (Räisänen 1978: 332.)

In this article, I have used a slightly different naming system for the loanword adaptation patterns, but I also compare the adaptation patterns to Räisänen's word formation patterns.

Such terms as word form (sanahahmo) and model (muotti) are also widely used when speaking of using models to adapt new words to a language (e.g. VISK $\$ 147-148$; Koivisto 2013: 167-210). However, both of these terms may be combined under the term analogy. As the international literature does not use the term model, I use only the term word form here when referring to irregular methods of loanword adaptation.

In Finnish, as well as in Saami, many ${ }^{*}-e T A$ adjectives do not have a free stem. In the tradition of research on Finnish, the derivativeness of a word form has been seen as continuum (VISK $\$ 149$ ). Only the ${ }^{*}-e T A$ adjectives with a free stem are considered derivations, and VISK (ibid.) does not mention even one of such adjectives as pure derivations. Some ${ }^{\star}-e T A$ adjectives are mentioned as blurred derivations, such as lempeä 'gentle' < lempi 'love' and pyöreä 'round' < pyörä 'wheel'. Correlational derivations are a separate group and include words such as synkeä 'dark, dim', which has correlate synkkä 'id.', as well as jyreä 'steep' jyrkkä 'id.'. Such variation in suffixes is typical of derivation in Finnish. Completely opaque ${ }^{*}-e T A$ formations include e.g. säyseä 'calm, tame' (VISK $\$ 149)^{6}$, and these are called non-derivatives.

The phenomenon of suffixal variation has been approached from different angles in many studies. Mauno Koski (1982: 74-99) presents two dif- 
ferent approaches for how to treat opaque word forms; a criterion based on the stem (alkukriteeri), and a criterion based on the ending (loppukriteeri). If we look at the stem of the word, the forms that have no stem correlate are monomorphemic, e.g. of the nouns with the ending -e: vene 'boat' has no correlate. However, the word haaste 'challenge' is a derivation, as it has a correlate verb haastaa 'to speak; to challenge'.

The criterion based on the ending treats all words that have the same ending alike. Koski (1982: 74-99) uses nouns with the ending -e as an example here as well, and says that words such as vene 'boat' and haaste 'challenge' would be both treated as derivations accordingly. However, he sees this as problematic, as derivations would also include words that have no correlates, and the morpheme $-e$ has no semantic contents: it does not act as modifier or word class changer. Most of the ${ }^{*}-e T A$ formations in Finnish and North Saami have no such problem regarding their semantic contents. They are almost all adjectives. Many of them have also correlates, as we will see in this study, the etymological relations may be different from the cognitive relations. However, in forming new words the correlative pairs work as models for new formations (Räisänen 1978: 332). Koski (1982: 99) emphasizes that the diachronic word formation process and synchronic monitoring of derivations are not alike. In examining the synchronic lexicon, the focal point is pinpointing the correlates, although the correlations can be different both morphologically and in their formal derivational processes.

Osmo Nikkilä $(1981 ; 1998)$ refers to variation of the type vireä, virkeä, virkku 'lively', and also nopea, nopsa 'swift' using the term suffix change (suffiksinvaihto). This is based on structural re-interpretation of a word form, in which the last syllable of a diachronically morphophonemic word is interpreted as a suffix that can be replaced with another. Koski (1982: 89) presents the word pair kuningas 'king' and kuningatar 'queen' as an example: the word kuningas has been restructured so that the last $-s$ has been interpreted as a suffix. By replacing the $-s$ we create a female form by adding the domestic feminine suffix -tar to the stem kuninga-. The stem kuninga- is bound, as it cannot occur alone. Still, forms can be derived from it using suffixes. Koski (ibid.) says that the ending -s has not become marked, e.g. +MASCuline, due to the word pair (koiras 'male' $\sim$ naaras 'female', of animals and plants). In fact, it may be interpreted as a masculine marker in words denoting humans, e.g. ruhtinas 'duke' and ruhtinatar 'duchess'. 
Adjectives have a strong tendency to exhibit allomorphic variation, probably due to the need to enliven and refresh their expressive capabilities. Nikkilä (1998: 79) says that the aim of etymological research concerning such words with varying suffixes (or endings) is to find out the possible etymon from which the variation originates. Nikkilä shows patterns of variation and reminds us that the variation should not be explained based on "descriptivity" or sound-symbolism.

In general linguistics, word-form recognition is an important part of cognitive categorization and has been studied especially in psycholinguistics. The process by which a suffix is added to a non-word stem is called pseudo-affixation (see e. g. McQueen \& Cutler 1998). For instance, the English word bulky is a regular derivation from bulk, but although the word class is the same, the word nasty has no basic word. Despite the lack of a base, it is recognized as the same word type as bulky. Aronoff and Fudeman (2005: 111-2) include the word nasty in word-form recognition and count this type of words under term affixation, just like the regular derivation bulky. The stems are either free (bulk>bulky) or bound ${ }^{* *}$ nast / nasty). In this article, I use the term affixation when speaking of adding a suffix to a foreign stem that does not occur independently in the language (section 4.3.).

Räisänen (1978) also presents a cognitive approach to the suffixal variation, although he does bear in mind the diachronic approach alongside the synchronic. He points out that derivation patterns do not tend to follow the rule $\mathrm{a}>\mathrm{b}>\mathrm{c}$ in a speaker's cognition, even if it were etymologically true. The speaker uses word-forms and models as patterns in deriving new words, and these patterns do not need to be complete. Räisänen (1978) has discussed how speakers understand the border between derivation and stem. He also has doubted the generativist viewpoint on the regularity of derivation processes and studied empirically how speakers associate derivations with stems. He argues that the cognitive contact between stems and derivations differs from the diachronic development of derivations. However, the cognitive association may lead to the formation of new words, and thus the cognitive approach should be kept in mind also when dealing with the etymological point of view.

Based on his empirical test, Räisänen (1978: 330) argues that the word derivation is based more on semantics than on morphological structure, although the structure, if it has semantic contents, seems to play an important role in structural re-interpretation of a word form, as presented 
above using the English examples. I have noticed that the word structure is important when a speaker assumes derivation patterns. One example is a question of derivation made to senior-secondary students. They assumed that adjective makea 'sweet' is derived from maku 'taste', although diachronically the noun maku is a derivation of makea. However, the threesyllable word is recognized as a derivation, as it is longer than the twosyllable maku, in which case one must study historical linguistics in order to know that the endings $-o$ and $-u$ are derivations. Räisänen (1978: 330) argues that such thing as a stem, or only one stem, is not very usable in the word formation process. For a speaker, there is only a group of words with a similar stem, and this knowledge is used in forming new words.

By studying words etymologically, we can see which words are derivations and which have been borrowed as a whole. Here we come to a question: should we treat these words differently? The only way to detect whether a word is a derivation or not is through etymology. This means that for a speaker it does not make a difference which background the word has. Word-form recognition is more significant than the etymological background of the word because the form tells the speaker the function of the word (McQueen \& Cutler 1998: 415-416). Most of * ${ }^{*}$ TA-words in Finnish and all in Saami are adjectives and this feature is much more important than whether it has an existing stem or not. Thus, we may assume that all adapted words have affected or at least indicated the productivity of this suffix and it is unnecessary to make a difference between the bound-stem and free-stem forms, as long as they are recognized as adjectives. Based on this, we may call *-eTA a derivative type, although in research on Finnish, the ${ }^{*}-e T A$ type has also been called an inflectional or stem type.

\subsection{Productivity}

When we speak of suffixes and derivation, it is important to pay attention to productivity. Morphological productivity is nowadays considered more of a continuum than a polar phenomenon (e. g. Bybee 1985: 132-135; Aronoff \& Anshen 1998; Aikhenvald 2007). At one end of the continuum are the dead or completely unproductive affixes that are not likely to be used in coining new words at all. At the other end are highly productive affixes that can be added whenever syntactic conditions are appropriate and there are no other forms blocking them. (Aronoff \& Anshen 1998: 243.) Vesa Koivisto (2013: 234) adds that it is not only suffixes that are productive, but 
also word forms. In this study, it is impossible to study the level of productivity because the study concentrates on only one adjective suffix. However, it can be argued that the suffix is productive at some level if new words can be formed using it. Thus, we can assume that if the derivative type has gained loanwords, it has been productive enough to accept new words at the time when the loanword was assigned to the language, regardless of the adaptation method. A large influx of new loanwords may have an increasing effect on the productivity of a derivative type (Koivisto 2013: 207).

\subsection{Finnic *-e $\delta A$}

In the Finnic branch, the PFP suffix ${ }^{*}-(e) T A$ has developed into ProtoFinnic * $-e \delta A$ and occurs e.g. in Finnish in the form -eA (kapea 'narrow', dialectally also in forms -ee, -ie, -ia), in Karelian as -ie (kapie 'narrow' < ${ }^{\star} k a p i a<{ }^{*} k a p e a$, Ojansuu 1918: 110, 118), in Veps as -ed and in Estonian as - $e$ in nominative and -eda in partitive (e.g. nom. pime, part. pimeda'dark (of light)').

The function of the suffix ${ }^{*}-e \delta A$ is primarily adjectival in all present Finnic languages. The derivation type includes only a handful of nouns, such as the Finnish hopea 'silver'. All of these nouns have been semantically lexicalized from adjectives. The original adjectival denotation 'soft' of hopea is still visible in its cognates e. g. in Lule Saami suohpe 'soft, elastic; easy to work with'8 (SSA 1: 172; Lehtiranta 2001: 128). Adjectives with the ending ${ }^{*}-e \delta A$ are largely represented at least in the dictionaries of Finnish and Karelian. Although the type-frequency (Bauer 2001: 48) of this derivative is highly attested, the suffix is usually considered unproductive. However, the suffix also occurs with loanwords, ones that date back to the Finnic protolanguage and ones that have appeared later in individual languages.

The Finnic suffix *-e $\delta A$ shows allomorphic variation with the suffixes ${ }^{*}-k e \delta a$ and $-k k V$ (Hallap 1983; Nikkilä 1998; Rauhala 2011). Usually the suf$f i x{ }^{*}-k e \delta a$ is an allomorph that does not significantly change the meaning or function of the adjective. It is common for the suffix of an adjective to change without changing its meaning, e. g. Finnish vireä $\sim$ virkeä $\sim$ virkku 'lively'. Apparently the suffix ${ }^{*}-k e \delta a$ has also been used as an independent suffix, as the adjective vaikea 'difficult' seems to be derived from the noun vaiva 'trouble; pain' (Nikkilä 1993: 283). Nikkilä (ibid.) suggests that the form vaikea would have been derived from vaiva by means of suffix change. 
He assumes that the ending - va in vaiva has been interpreted as a suffix, and that it has been changed to the adjective suffix -kea. However, it is not necessary to assume a reanalysed suffix for vaiva. Instead, we may assume a regular derivation whereby the adjective suffix - kea has been added to the stem vai-, because the suffix can be added only to monosyllabic stems. Phonologically it would have also been possible to form ${ }^{* *}$ vaivea, but this does not seem to exist, at least not in Finnish. In the eastern dialects of Finnish and in Karelian this type of suffixal variation is more regular than elsewhere in Finnish. The variation is connected to the "expressive" nature of the vocabulary with which it is used. In this study, I use the term "expressive" as a semantic term. Expressive words are words that denote affective concepts and/or carry either negative or positive affect (Kulonen 2006: 323-324; Aikio 2009: 26-27). Thus, words with the ending $-e A$ are used widely in colloquial Finnish (where $-e A>-e e$ ): rouhee 'cool', kähee 'coarse (of a voice); cool'.

The traditional, Neo-grammarian idea is that suffix development has phases. For example, the adjective suffix studied here has supposedly been ${ }^{*}$-TA in the Finno-Permic (or Finno-Ugric) protolanguage. It has then gained the stem vowel ${ }^{\star}-e$-, perhaps in the Finno-Saamic protolanguage, as suggested in section 1 . At this point, the stem has been reduced to a monosyllabic form. This causes large variation as well as homonymy with other words. It also may have led to the contemporary situation in Finnic, where the suffix ${ }^{*}-e T A$ exhibits much variation and is used in expressive vocabulary. In order to preserve productivity, the suffix must have some meaning that withstands homonymy. Expressive and sound-symbolic vocabulary may better withstand homonymy because the focus is not on clear denotation, but on affect.

Finnish gained new -eA-derivations in the 19th century via language planning; e.g. jauhea 'floury (in botanical terminology)' < jauho 'flour's (Pitkänen 2008: 193). Päivi Rintala (1978: 154-155) considers suffixal productivity in language planning to be a special case of productivity. Language planning in Finnish has used domestic elements, stems and suffixes, and it has also employed suffixes that were no longer productive. This type of intentional word formation process is traditionally called creativity and e. g. Bauer (2001) does not count it as part of productivity. Aronoff \& Anshen (1998: 246) criticize the scholars who tend to discard such intentional word creation, as it entirely rules out the study of unproductive morphology. The less productive affixes tend to be used in order to make a special 
Adaptation of loanwords of the suffix type *-eTA in Finnish and Saami

point or emphasize the terminological sense. From Aronoff \& Anshen's point of view, it is understandable that language planning has used such unproductive suffixes in new terminology.

\subsection{Saami *-etē}

In the Saami languages, the Finno-Permic suffix has developed into ProtoSaami * ete (Aikio 2006: 36) which in North Saami has developed into -at. As in Finnish, the suffix -at in Saami is added to monosyllabic stems and produces trisyllabic words.

The adjective class in Saami is morphologically distinguished from nouns in a way that is unique among Uralic languages. Most of the adjectives have two morphologically separate forms, one for predicative adjectives and one for modifiers. The adjectives can be coarsely divided into three groups according to the form of the modifier: 1. the modifier is the same as the singular nominative (gielalaš 'linguistic', divrras 'expensive'), 2. the modifier ends with -s (čeahppi, mod. čeahpes 'skilled', njuolgat, mod. njulges 'straight'), 3. the modifier ends with - a (allat mod. alla 'high', garas mod. garra 'hard, harsh', odas, mod. odda 'new') (Nickel 1994: 80). The -at adjectives studied here belong to the second group: the adjectives with the ending -at (in genitive-accusative - $d a$, e. g. ruoksat:ruoksada) usually have -es in the modifier form: ruoksat 'red (predicative)', rukses 'red (modifier)':

\section{a. biila lea ruoksat 'the car is red' \\ b. dat lea rukses biila 'that is a red car'}

Sometimes the modifier may be in the form -adis, which seems to be an analogical long form in which the suffix -is is added to the genitive form. The change in merging the modifier concerns only adjectives, at least in North Saami. Demonstrative pronouns and numerals act a bit differently from adjectives. Demonstratives and numerals agree partly with their heads, i. e. the agreement concerns some cases, not all (Nickel 1994: 89, 116; Rauhala 2013).

The need to mark adjectives separately from other word classes means that new words have to be categorized. Thus, adjectives tend to need adaptation so that the new word fits the native system. Today, the default adjective suffix for forming new adjectives is -laš, e. g. magnehtalaš 'magnetic'. It has no separate modifier form. 


\section{Processes of assigning loanwords containing *-(e)TA}

In the following section, I analyse the loanword data of Finnish and North Saami * ${ }^{*}$ TA adjectives. I have divided the data into three categories based on the method by which the words have been adapted to the language. Derivation (4.1.) is the most transparent way of adapting loanwords to the language. Derivation is divided into two types. The first, regular derivation (4.1.1.) is for cases where the words follow the regular rule of adding the *-eTA suffix to the monosyllabic root. The section "Other derivations (4.1.2.)" is reserved for word forms that do not follow the suffixation rule perfectly but are still derived from an existing stem.

The second method is morphological adaptation (4.2.), in which the borrowed word form has been adapted to the derivative type *-eTA. Morphological adaptation (Haspelmath 2009) can be divided into different types based on the way the words are adapted. In morphophonological adaptation (4.2.1.) the word is adapted to the ${ }^{*}-e T A$ formal type based on its phonological form in the donor language and the closest form in the recipient language. The morphological aspect comes into the picture when a speaker reanalyses the borrowed form as a derivation and gives it the adjective function that ${ }^{*}-e T A$ words have. Etymological nativization (4.2.2.) (Aikio 2007) is used when borrowing from a related language. In etymological nativization, the adaptation is based on etymological cognates, which work as models for new formations. New loanwords are adapted to the system analogically to the old cognates. A similar process to etymological nativization is analogical adaptation (4.2.3.), where the donor language and recipient language are not necessarily related, but words are analogically adapted to the ${ }^{*}-e T A$ suffix type based on the earlier borrowed vocabulary.

Affixation (4.3.) (Aronoff \& Fudeman 2005: 110) is, in a way, related both to derivation and morphological adaptation. The suffix ${ }^{*}-e T A$ is added to a foreign stem that does not occur in basic form in the language, e. g. North Saami roaffat 'coarse'. 
Adaptation of loanwords of the suffix type *-eTA in Finnish and Saami

\section{I. Derivation}

\section{I.I. Regular derivation}

Regular derivation is usually considered a mechanical formation process, wherein a suffix is added to a stem to form a new word. Unlike inflection, derivation usually forms new words and derivative suffixes are used e.g. to change the word class of a word (Bybee 1985: 81-87), e. g. bulk (noun) > bulky (adjective). The derivative suffix ${ }^{*}-e T A$ marks adjectives. In regular derivation, the suffix ${ }^{*}-e T A$ is added to an existing stem using the following rule: the suffix ${ }^{*}-e T A$ is added to the first syllable of the stem. Regular derivation is usually used to change a noun into an adjective, but there are some examples where the word class does not change: the adjective is changed into another adjective. The meaning may be slightly altered in the process, but the semantic change is not regular.

The data presented here demonstrates the regular derivation used in loanwords, or better put, borrowed stems. Usually derivations are not considered loanwords, although they have been formed from loanwords. However, in studying the ability to adapt new words to a suffix type it is also crucial to look at the loanwords from which the new forms have been derived.

Finnish

Baltic loanwords

1) hallea (dial.) 'light grey'? < Fi halli 'greyish, light grey brown animal; grey seal' < Fi halla 'frost' < PFS *šalna (> PSa *suolnē $>$ SaaN suoldni 'dew; haze') < PBalt *šal- (> Lit šalnà 'frost; mild freeze' šalns 'roan') (SSA 1: 133; Sammallahti 1998: 124).

Derived from either halla or halli. The form hallea has no cognates in other Finnic languages.

2) kärmeä 'sharp (of axe); fast, slippery' < (dial.) kärmes 'snake' (literary Fi käärme 'id.') < PBalt, cf. Lit kirmiś 'worm' (SSA 1: 476).

= Vot kärmiä 'fast'; Est kärme 'quick, agile' (ibid.).

Germanic loanwords

3) pullea 'plump, chubby' < PFi ${ }^{\star} p u l l V-<$ PFS ${ }^{\star} p u l n a\left(>\mathrm{PSa}{ }^{\star} p o l n \bar{e}>\mathrm{NS}\right.$ boldni) < PreGerm ${ }^{\star}$ fulna- (> PGerm ${ }^{\star}$ fulla 'full') (Aikio 2006: 18). = Kar pullakka 'plump, chubby; bloated'; Est (dial.) pullas 'chubby'. The variation in the forms of pullea in the Finnic languages suggests that the adjective suffix has been acquired independently in different areas. 
Scandinavian loanwords

4) $k a r p(p) e a$ 'hard crusted (of bread); scrubby, stunted' < karppa 'frozen snow, hard, frozen ground; salt coating on meat; soot' < Scand cf. Swe skarp, Eng sharp (SSA 1: 316).

No formal cognates in other Finnic languages.

5) pramea, ramea 'handsome; pretentious, puffy' < prami 'handsomeness' $<$ Swe bram 'handsomeness, pride, pretentiousness'. (SSA 2: 408; NSES 2004: 954.)

No cognates in other Finnic languages.

The Finnish adjective pramea (example 5) is a rather young loanword, and it is regularly derived from prami 'handsomeness', which is borrowed from Swedish. The derivative pramea occurs in literary texts from the end of the 18th century, although prami is older and also occurs in Agricola's texts (NSES 2004: 954). However, in the Old Finnish there has been a derivative pramius 'handsomeness' (ibid.), which indicates the existence of pramia (the south-western dialectal form of pramea). This suggests that the derivation process has been productive at some level in the 18th century. The $-e A$ derivatives made by Lönnrot in the 19th century (Pitkänen 2008: 193-194) may also have been possible in spontaneous language use, not only in intentional terminology.

The Finnish data presents old Baltic and Germanic loanwords, of which some still also exist as underived words (examples 1, 2 and 4). Only the germanic loanword pullea 'plump' (example 3) does not seem to have an existing stem. The data also includes a rather young Swedish loanword (5) that has been regularly derived with suffix * eTA. Sometimes the * eTA derivations also exist in other Finnic languages than Finnish. However, the examples above demonstrate that their existence is mostly restricted to Finnish.

\section{North Saami}

Germanic loanwords

6) sáhppat 'bluish, purple' < sáhppi 'berry juice' < some form based on PGerm ${ }^{*}$ saf/ppan- (> Eng sap) (the PGerm. reconstruction is from Kroonen 2013: 420).

No formal cognates in other Saami languages. The distribution of cognates for sáhppi 'berry juice' is wide in both the east and the west. (Álgu.) - New etymology. 
Adaptation of loanwords of the suffix type *-eTA in Finnish and Saami

Scandinavian loanwords

7) roađđat 'fiery red' < roađđi 'sunrise or sunset' < Old Norse rođi 'id.' (Álgu). = SaaLu rāté 'red sky'; SaaIn roađi 'red morning sky'.

Does not occur as a derivative in other Saami languages.

Finnish loanwords

8) veahkat 'strong, potent; powerful' < veahka 'men, help; crowd; strength, potency; manure, fertilizer' < Fi väki 'people' (Aikio 2007: 35).

North Saami also has some regular derivations of loanwords (6-8) that are diachronically interesting; the oldest loanword is from Proto-Germanic (6) and the latest is from Finnish (8). The word sáhppat (6) is a bit complicated. It is probably derived from sáhppi 'berry juice'. In dictionaries, the denotation 'berry juice' has been connected to sáhppi 'gall'o. These two denotations of sáhppi are presumably homonyms and do not belong together etymologically. The claim is based on semantic development. It is not probable that the denotation 'gall' could develop into 'sweet juice', nor does such a development occur in any other Finno-Ugric languages. The only semantic development from 'gall' into something to drink is into 'booze', which has happened in Mordvin (MdWb: 1968). In Mordvin, the adjective derived from the noun 'gall' also means 'gallish, bitter' (ibid.). A more plausible explanation for sáhppat is a rather early borrowing from the Proto-Germanic *saf/ppan (> Eng sap) or the Scandinavian protolanguage to Proto-Saami. The Swedish saft 'juice' has been borrowed from Old High German saft (Hellquist 1922: 685). This etymology suggests that the Proto-Scandinavian has had a cognate to PGerm ${ }^{*}$ saf/ppan but it has disappeared.

Nielsen (1938: 380) has translated the word sáhppat as 'bluish'. He gives an additional explanation that the word sáhppat is used in some dialects used to denote a red face cloth that does not have a clean red colour. The word actually means 'purple', which is a typical colour of berry juice. The colour term sáhppat is restricted to North Saami, which suggests that it could be a rather young derivation. 


\section{I.2. Other derivations}

Not all derivations can be considered regular, even though the root forms exist. Problematic features include the lack of a change in word class, where an adjective produces another adjective (examples 9, 11-12). However, the forms can be recognized as derivations, as they have existing basic stem.

9) helpeä 'weak, thin; light; quiet, slow; comfortable' < helppo a. 'easy; small; light; cheap, worthless; slow; mild' < PGerm. ${ }^{*} x e l p \bar{o}$ (> Swe hjälp, Eng help) (SKES 1955: 67; SSA 1: 154).

= Kar helpie 'weak, thin; quiet, slow; nice'.

The PFi word ${ }^{\star} h e l p p o$ has a wide distribution in Finnic. It occurs also as a noun, which would partly explain the need for derivative form with *-eTA. (LÄGLOS 1: 93.)

10) vaikea 'difficult' < vaiva 'trouble; illness' (also in Karelian) < PGerm *waiva- (> Old Swedish $v \bar{e}, v \bar{e}$ 'unhappiness, misery; pain') (Nikkilä 1993: 283; on the etymology of vaiva, see SSA 3: 394; LÄGLOS 3: 357).

= Ing vaikia 'difficult'; Kar vaikie 'difficult, burdensome'; Vot vaikęa 'difficult, burdensome; tough (of wind); strange (of a person); (n.) difficulty' (SSA 3: 391).

11) lauhkea 'mild; soft', lauhea 'id.' < lauha 'mild (of weather); soft' ? < PGerm *lausa-z (Tunkelo 1913-18: 14-16; LÄGLOS 2: 177).

= Ing lauhkia 'mild (of weather)', Kar. lauhkie 'mild (of weather); gentle', lauhie 'mild, soft' (LÄGLOS 2: 177).

In particular, the Finnish helpeä (example 9) is difficult to see a regular derivation for two reasons: firstly, it is not derived from a noun. Instead, it is derived from an adjective that has the same meaning. Secondly, it is not derived from a form ${ }^{*}$ helpa. It has been assumed that the suffix ${ }^{*}-e T A$ would have been able to be added to words ending $-a$ or $-i$. However, it seems that in Finnish this phonological rule has disappeared and the suffix has also been added to other words. The reason for this may be the appearance of nouns ending in $-o$ and $-u$ in the Finno-Saamic protolanguage. Another possibility is to consider this an instance of correlational derivation (Räisänen 1978). This would mean that the word helpeä has been formed from helppo by using word pairs, such as valkea 'white' and valkko 'white animal', or virkeä 'bright, alert' and virkku 'id.' as correlates. Nikkilä (e. g. 1998) would probably add the forms helppo and helpeä under suf- 
fix change, if one assumes that the form helppo has been structured as a derivation, and the $-o$ as a derivational suffix.

It is known (e.g. Hallap 1983) that the suffix ${ }^{*}-e T A$ has an allomorphic variant ${ }^{*}-k e T A$, at least in Finnic. This allomorphic variation can be seen e. g. in example 11, where the form lauha has produced both derivations lauhea and lauhkea. The adjective vaikea (example 10) is also formed with ${ }^{*}-k e T A$, although the parallel form ${ }^{*}$ vaivea is not attested. The suffix ${ }^{*}-e T A$ also alternates with the suffix $-k k V$, as in Finnish navea navakka (example 31). In North Saami, the form čuorri 'grey' (example 12) is phonologically closer to the Proto-Aryan form; I assume that the form čuorgat has been derived from čuorri. In assuming that the form čuorgat is a derivation of čuorri, one also has to assume that ${ }^{*}-k e T A$ was an existing variant in Saami. A possible parallel to support this is the adjective njuolgat 'straight', which could be derived from njuolla 'arrow'. It is noteworthy that both in Finnic and in North Saami the most common consonant before the suffix ${ }^{*}$-eTA is $k$ (of Finnic, see Nikkilä 1981 and Hallap 1983; the calculations for North Saami vocabulary are my own). If both suffixes ${ }^{*}-e T A$ and ${ }^{\star}-k e T A$ already existed prior to Proto-Finnic, it would perhaps explain the vast existing variation involving ${ }^{*}-e T A$ and ${ }^{*}-k e T A$ in the Finnic languages. In addition, it would mean that the speakers of Proto-Finnic had parallels (or correlations, as called in Finnish studies) to use in the formation of new words.

\section{North Saami}

Aryan loanwords

12) čuorgat 'grey (of hair)' ? < čuorri 'grey' < PFS ^śaras < PAr `śará (Sammallahti 2001: 399).

Wide distribution in the Saami languages.

\section{North Saami}

Baltic loanwords

13) šearrat 'bright, clear' < PS *̌searețē < PBalt. “̌̌er- (> Lit žéréti, žéruoti 'to shine brightly, to sparkle') (Sammallahti 2001: 401; Aikio 2009: 199). Wide distribution in Saami.

14) lávgat 'tight-fitting' ? < lávgat 'fit tightly' < PS *lāyve < Scand. cf. ON lagga, perf. part. løgðr 'fold' > Swe log (Álgu). 
The North Saami šearrat 'bright, clear' (example 13) is a loanword from the Baltic protolanguage. The Baltic stem occurs in many other words, e. g. šearus 'clear (of sound, voice, intellect); sharp (of a picture), free from dirt (of a window)' and šearrát 'be clear' (Álgu). Aikio (2009: 199) has assumed that šearrat (<PS šearetēe) is derived from the PS root ${ }^{\star} \check{s}_{e} e a r \bar{e}-$, which does not occur as a free stem in any contemporary Saami language. Räisänen (1978: 331) argues that such a stem does not need to have existed at all, which may be the case for the word group of šearrat. The same thing may be true of lávgat 'tight-fitting' (example 14), unless it is derived from the verb lávgat 'fit tightly'. If this is the case, then this adjective suffix would be not only denominal but also deverbal, at least in North Saami.

\subsection{Morphological adaptation}

One way to attest loanwords is through morphological adaptation, in which loanwords are adapted as whole entities and assigned to specific word types. According to Räisänen (1978: 334), it is easier to memorize and spread a word that has been adapted to the domestic system, e. g. by morphological adaptation, than to memorize a completely foreign word. This reminds us that grammar is not independent from cognition. Thus, in the word formation process, both memory and the morphological rules of language are relevant (ibid.).

Some stems may have been developed from the borrowed derivatives as a result of back-derivation (on back-derivation, see also Räisänen 1978: $332-333)$. Strictly speaking, this is not a derivational process, as the word is borrowed as whole and the stem is a non-word, i. e. a stem that has no independent meaning. However, the speakers recognize the word as consisting of more than one morpheme although the stem itself has no independent function (Aronoff \& Fudeman 2005: 111-112). Instead of a derivative type, this can be seen as inflectional type that increases also by adopting new loanwords as whole instead of by derivation. However, morphological adaptation should not be overlooked in studies of morphological productivity. In addition, the formal variation seen in adjectives in Finnic languages suggests that not only free stems but also bound stems are recognized as stems that can be varied with suffixes (Nikkilä 1998). Räisänen (1978: 339) calls this type of derivation model-word derivation, for which it is typical that the stem of the derivative is a non-word. 
Morphological adaptation can be divided into different types. Morphophonological adaptation is the type in which loanwords are adapted to the recipient language with changes to their phonological form (example 15). Etymological nativization is close to morphophonological adaptation, but the nativization in this case is based on the knowledge of a common etymological form between the languages, such as Saami and Finnish (Aikio 2007). Such knowledge is possible for an average speaker due to long and intensive language contacts, and bilingualism. The common Finno-Saamic words can be recognized and new words can be created using the same rules. For example, the SaaN word haddi 'price' is a loanword from Finnish hinta 'id.', but only the initial $h$ reveals it a loanword, as the Finnish $h$ is a new consonant and usually traceable back to $\check{s}$, which should be $s$ in North Saami. If the Saami word were common with Finnish, it would occur in the form saddi. The first syllable $-i$ - and the second syllable $-a$ - are substituted using the same rule as that occurring with common words, e. g. SaaN albmi 'sky; storm; air' = Fi ilma 'air'. The consonant cluster is also substituted using the same rule as for common words, e. g. SaaN guoddit 'to carry' = Fi kantaa 'id.'(Álgu, s. v. guoddit). Thus, it is a form of analogy and may also take place with late borrowings (examples 19-30). The last adaptation type is analogical adaptation. One could argue that etymological nativization and analogical adaptation should be seen as a common type. Both types use the same analogy. New loanwords of a certain type (e. g. words ending with -as, no matter which language) are borrowed into the same suffixal type as the older ones.

\subsection{Morphophonological adaptation}

(Morpho)phonological adaptation is based on substitution rules by which the loanwords are assigned to the language. If the loanword's sound system is close to some suffix type of the recipient language, the word may be substituted into it. Of course, the substitution requires the borrowing to fit semantically with the suffix type. The suffix *-eTA marks adjectives, so the borrowing has to be an adjective or it has to be able to become an adjective.

\section{Finnish}

Russian loanwords

15) apea 'depressed, unhappy; rueful' < Rus. obída 'insult' (SSA 1: 78). = Kar apie (n./adj.) 'grief; sad, wistful'; Lud abid (n.) 'sorrow, pain; insult'; Vep abid (n.) 'grief'; VepN abed (adj.) 'annoying, irritating'. (ibid.). 
The only word filling the substitution rules is the Russian loanword apea. Phonological similarity may lead to a change in word class in the process of acquiring a loanword. The Russian noun obida 'bitterness; insult' (example 15) has been borrowed by various Finnic languages: Finnish, Karelian and the north dialect of Veps have adapted the loanword to the derivative type ${ }^{*}-e T A$ and, due to the adjectival function of the suffix, the word class has changed from noun to adjective. The Veps abid is still a noun, but it is also formed differently as it has been borrowed directly without changing the last vowel into - $e$-. It is probably borrowed later than the adjective form. Lude has also a form abid, which is a noun, not an adjective. In Lude, the adjective suffix * eTA has developed into -ed, e. g. pimed 'dark (of light)'.

Another way to see the Russian loanword is as an instance of structural reinterpretation. It does fit well in light of the etymology and change in word class. In the process of borrowing the Russian obida into Finnic, the reinterpretation has led to a change in word class from noun to adjective.

\subsubsection{Etymological nativization}

North Saami has adapted a large number of loanwords from the ProtoFinnic formal type *-e $\delta A$ (examples 16-18) and later from Finnish -eA (examples 19-30). This type of adaptation is easy to make, as the suffixes are cognates (see more on Aikio 2007). This process suggests that the speakers of the receiving language have recognized the Finnish suffix - $e A$ in the donor language as being the same as -at in their own language, plausibly due to long, intensive contacts and bilingualism (Aikio 2007: 17). Etymological nativization is not restricted only to suffixal similarities: other phonemes are also substituted with former cognates, although in regular loans they should be substituted differently. For example, the word haddi 'price' < Fi hinta 'id.' is a loanword, although the vowels make the words look like cognates (see the explanation in the introduction of 4.2.). However, etymological nativization does not necessarily affect every phonological segment in a word (Aikio 2007: 44).

North Saami

Proto-Finnic loanwords:

16) goarrat 'arrogant; fastidious' < PS * kore- < PFi ${ }^{\star} k o r e \delta a(>$ Fi korea 'beautiful; colourful, bright; excellent; proud, picky') (SSA 1: 402). Wide distribution across the Saami languages. 


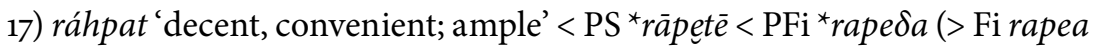
'quick, brisk; ample') (SSA 3: 50).

Wide distribution across the Saami languages.

18) šallat 'shiny and smooth (esp. of a bad whetstone)' $<$ PS *̌šele - $<\mathrm{PFi}$

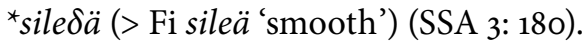

Wide distribution across the Saami languages.

The Proto-Finnic loanwords (examples 16-18) have a wide distribution in the Saami languages and they can be reconstructed to Proto-Saami. However, there are some phonological features that distinguish these loanwords from the common Finno-Saamic words. In ráhpat (example 17), for example, the PFi first syllable $a$ has been substituted with $a$, although the Proto Finno-Saamic first syllable $a$ has changed into uo in Saami. ${ }^{11}$ If the phonological substitution does not reveal a loanword, we may still expect a word to be borrowed if it is semantically abstract and the basic meaning can be found in Finnish along with the more abstract ones (e.g. girkat, example 44).

Finnish loanwords

19) váigat 'difficult' < Fi vaikea 'id.' (SSA 3: 394).

= SaaIn vajgad 'difficult, shrilling noise', SaaSk vaiggâd 'id.', SaaKld vaiga $\delta$ 'shrilling noise' (Álgu).

20) girrat 'heavy (of weather); harsh, sharp (of a voice)' < Fi kireä (SSA 1: 369).

No cognates. (Álgu.)

21) hilbat 'wild; unmanageable, shy, roving (of reindeer); careless; cheeky' < Fi hilpeä 'happy' or ylpeä 'proud' (SSA 1: 164).

= SaaIn ilbad 'mischievous', SaaSk ilbbad 'mean, cruel' (Álgu).

22) jolgat 'self-confident, frank' < Fi julkea 'shameless; open; valuable' (SSA 1: 246).

= SaaS julgedh 'to dare', SaaIn julga 'openly' (Álgu).

23) leambat 'warm' < Finnish lempeä 'warm, gentle' (SSA 2: 62).

No other cognates in Saami. The SaaLu libbes 'warm, gentle' (SSA 2: 62) does not belong here, as it is more probably a derivation from libba 'sheep'.

24) roahkkat 'daring, fearless' < Fi rohkea 'id.' (SSA 3: 86). = SaaLu råhkat 'brave', SaaIn ruokkad 'id.', SaaSk ruokkâd 'id.' (Álgu). 
25) goargat 'particular, swell; fine, magnificent' < Fi korkea 'high' (SSA 1: 403).

= SaaIn korgad 'proud' (Álgu).

26) surgat 'terrible; sad' < Fi surkea 'sad; terrible' (SSA 3: 221).

= SaaS surgedh 'be sad; worry'; SaaPi surŭkat 'id.'; SaaLu surkat 'sorry'; SaaIn surgad 'terrible, sad' (Álgu).

27) gáfat 'terrible; peculiar' < Fi kauhea 'terrible' (SSA 1: 330).

No cognates.

28) sáhkat 'thick' < Fi sakea 'id.' - New etymology.

= SaaIn saahad 'thick' (Álgu).

29) gággat 'stiff' < Fi kankea 'id.' (SSA 1: 299).

= SaaIn kaggad 'id.' (Álgu).

30) sitkat 'tough; enduring, persevering; even-tempered' < Fi sitkeä 'chewy; resilient' (SSA 3: 189).

= SaaIn siđhes 'id.' (Álgu).

The Finnish loanwords have been adapted to the same suffix type as the older Proto-Finnic loanwords. The distributions of the later borrowings from Finnish are more restricted than those of the Proto-Finnic ones. The later loanwords tend to have an eastern distribution, usually restricted to languages that are spoken within the Finnish borders: North Saami, Inari Saami and Skolt Saami. They may also sometimes occur a bit more west in Lule Saami, a close relative and western neighbour to North Saami. Some loanwords can also be found further east, but some of these loans may also have come via Karelian (see e.g. Rießler 2009 on Karelian loanwords in Kildin Saami). The only distributional exception in the data here is surgat (example 26), which has wide distribution extending as far as South Saami. It has been suggested as a cognate of Scandinavian sorg 'sadness, worrying' (Lagercrantz 1939: 822), but e. g. Korhonen (1981: 38) gives it a Finnish loan etymology. Korhonen's suggestion seems more correct because the first vowel is $u$, not $o$. Friis's old Saami dictionary (1887: 659) seems to include a word soarga 'grief', which (if the word soarga is a separate word from surgat) would be the phonologically correct form to have been borrowed from sorg. When such semantically and formally close word groups have been borrowed, it is possible that they will mingle together. Such word groups could be analysed with the methods used by Jarva (2003), as he has studied the relation between Russian loanwords and expressivity in the eastern dialects of Finnish. 
Adaptation of loanwords of the suffix type *-eTA in Finnish and Saami

\subsubsection{Analogical adaptation}

Analogy plays a significant role in morphology, also in assigning loanwords. Some borrowing patterns may lead to an analogical model being followed, something like etymological nativization in 4.2.2. (e. g. modelword derivation and correlational derivation, Räisänen 1978). Analogical adaptation is a term that I use to refer to adaptation in which the words are adapted by using the knowledge of older loanwords and how they have been adapted to the language. Analogical adaptation is practically the same as the etymological nativization process presented in 4.2.2., but the donor and recipient languages are not necessarily related to one another. As is the case for etymological nativization, long, intensive contacts and bilingualism are the reasons for analogical adaptation. We could also refer to this using Räisänen's (1978: 339) term "model-word derivation”, which emphasizes the cognitive aspect of the word formation process.

\section{Analogical adaptation in Finnish}

Germanic loanwords

31) navea 'hard, strong', navakka, napakka < PGerm ${ }^{\star}$ snaww ${ }^{i} j a-z$ (> ON snøggr 'swift') (NSES 2004: 776; LÄGLOS 2: 296).

= Kar ńavakka, ńavakko 'swift, hard (of wind); shrilling (of a voice)'.

32) makea, maajas 'sweet' < $\mathrm{PFi}{ }^{\star}$ makjas < PGerm ${ }^{*}$ smakjaz (> PHGerm smak, smake 'taste').

Both makea and maajas have a wide distribution in Finnic. (Itkonen 1982: 321-322; SSA 2: 134, 141.)

33) huokea, huojas 'cheap, affordable' < PGerm ^högiz (> ON høegr 'easy; adaptive; nice').

= Ing hōkia 'cheap, affordable'; Kar huovis 'cheap'; Lud huogiš 'cheap, affordable'; Vot ōkęa 'id.' (SSA 1: 185).

34) lausea 'shallow, low, even', lausas 'soft (of wood); gentle (of an animal, person); mild (of weather)' ? < PGerm. *lausaz 'loose; empty; false' (SSA 1: 55). The ${ }^{*}$-eTA form does not occur elsewhere in Finnic.

In the Finnic branch (examples 31-34), we see an analogical pattern in which the forms ending in -jas alternate with forms ending ${ }^{*}-e T A$. This variation occurs with Germanic loanwords. Itkonen (1982: 125) assumes that the different stem types that have occurred in Proto-Germanic have caused this formal variation. It is noteworthy that North Saami has used 
exactly the same suffix in adapting loanwords from Proto-Germanic and Proto-Scandinavian.

The form navea (31) is different from examples 32-34 as there is no form ${ }^{*}$ naujas. Still, we may assume that it is analogically adapted to the same derivative type as other Germanic loanword adjectives. As the forms huojas, lausas and laaja occur only sporadically, it is perhaps not surprising that form ${ }^{* *}$ naujas has not been attested anywhere.

Whether the formal variation has been caused by different forms, dialectal borrowing or borrowing from different stages of language, the fact is that there is rather regular formal variation which we can see in examples 9-11, and apparently also in 35 and 36. It is plausible that analogy has taken place at some point and new formal variants have been created regardless of the original form or etymological source. Such patterns may have offered a correlation or model by which to derive new patterns (Räisänen 1978: 339). Formal variation is typical of especially Finnish adjectives, and variation is created by using different derivational methods, such as the ones Räisänen suggests.

Scandinavian loanwords

35) lakea (southw. dial. lavia) 'even, open; sweet, docile'< PGerm ${ }^{\star}$ lāgijaz (> ON loegr 'calm, on one's side'; MLG lêch, lege 'low') or < PScand ^flakja(does not occur as an adj., but noun ON fleki 'fence, shelter; plaited station-roof' (SSA 2: 40).

= Ing lakkīa, Kar lakie, Lud, Vep laged, Vot lakęa 'smooth, even', Est lage, Liv la'gdo.

36) laakea 'even, open, low, shallow'? < PScand *lägija- (> ON loegr 'calm', Icel loegur 'even'), unless laakea is derived from laaka 'shallow, low; (stone) plate' < PScand *läga- (SSA 2: 31). No cognates in other Finnic languages (? > Vot lākia 'low').

The Proto-Scandinavian ${ }^{\star}$ flakja- looks phonologically similar to lakea or laaja. The suggested form in Proto-Finnic is ${ }^{*}$ lakja (Itkonen 1982: 129). The form laaja can be nicely traced back to ${ }^{\star}$ lakja, but the word lakea should be reconstructed to the form ${ }^{*} l a k e \delta a$, and it has wider distribution in Finnic than laaja. Itkonen (ibid.) assumes that lakea is an older form than laaja, and that it has been adapted to the ${ }^{*}-e \delta a$ adjective type soon after borrowing. Itkonen explains its adaptation to this type through some sort of analogy with such pairs as maajas, makea 'sweet' (32) and huojas, huokea 'cheap, af- 
fordable' (33). The Finnic ${ }^{\star}-e \delta a$ formations have been assumed to have been loans from the Proto-Germanic feminine ending ${ }^{*}$-ia (Itkonen 1982: 126). The connection between the PGerm forms with ${ }^{*}-k j a$ and the Finnic ${ }^{*}-e \delta a$ definitely do not show a phonological correspondence. It is also noteworthy that the ${ }^{*}-e \delta a$ formations ${ }^{*} h u o k e \delta a,{ }^{*} l a k e \delta a$ have a wider distribution in Finnic than ${ }^{\star} l a k j a$ and ${ }^{\star} h o \overline{k j a s}$ (Rapola 1966: 206). Thus, it is plausible that the adjectives have been marked with the adjective suffix ${ }^{*}-e \delta a$.

If the words maajas, makea (32) and huojas, huokea (33) have been borrowed from Proto-Germanic and laaja, lakea from Proto-Scandinavian, it means that the speakers already had a parallel by which to form the word pair, as also Itkonen (1982: 130) suggests. It is possible that both formations were made more or less simultaneously, and that the ${ }^{*}-e \delta a$ formation was made using the suffixal rules in Proto-Finnic, not via phonological substitution rules. The form with ${ }^{*}-e \delta a$ has perhaps been preserved better due to its clear adjectival content. The ${ }^{*}-j a(s)$ formation, on the other hand, has perhaps been unclear and thus not so usable, and it has therefore survived only sporadically.

The word laakea (example 36) also looks similar to its suggested donor word *lägija- in Proto-Scandinavian. However, LÄGLOS (2: 145) suggests that it is a contamination from lakea and laaka 'flat; (stone) plate', which, according to the semantics and distribution, seems more likely. The word laakea could also be a derivation of laaka, as SKES (2: 158) and Hakulinen (1979: 361) suggest. The possibility of derivation has been discarded based on the rarity of -eA derivations from $a$ stems. This, however, is not such a good reason to discard the possibility, as such derivation is not impossible. The adjective sokea 'blind' is a derivation of soka 'dirt, garbage; fish bone' (SSA 3: 194), and the word vaikea may be a derivation from vaiva (example 10).

The forms laakea (36) and lakea (35) could also be allophonic, as the form lakea occurs especially in western dialects of Finnish and laakea has a more eastern distribution. The same type of distribution is found for the forms halea and haalea 'lukewarm' (SSA 1: 125). Thus, we would not need to assume a different source for the close forms lakea and laakea.

Analogical adaptation in North Saami

Germanic loanwords

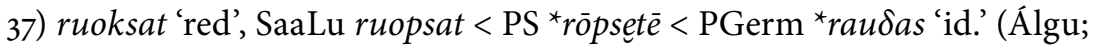

Sammallahti 1998: 128).

Wide distribution in Saami. 
38) deavkat 'dim' < PS ^teamkketēe < PGerm ^ ${ }^{\star}$ pemaz- (> OHG demar 'twilight, dusk') (Aikio 2006: 36).

Wide distribution in Saami.

Scandinavian loanwords

39) ruotnat 'green' < PS *rōnêtē < PScand grōniz (Álgu).

Wide distribution in Saami (Álgu).

40) luovvat 'which goes, works easily (of an implement); which does not hang back, drag (of a boat); easy to strip off (of skin); easy to smoke (of a pipe); which milks easily, is easy to milk (of a cow); loose (of the skin of a living animal); easy to mow (of hayfields)' $<$ PS $\star^{*}$ loves $<$ PScand *lausa-cf. Swe lös (Sammallahti 1998: 129; Álgu).

= SaaPi lu.ovvad 'loose, free' SaaLu luovvat 'id.' SaaIn luouvad 'easy to milk; easy to pluck (bird); easy to scale (fish)'.

41) snávgat 'limp, sulky' < Old Norse snøggr 'short-haired; swift' (Bergsland 1968: 145; Álgu).

= SaaS snavkie 'short-haired'; SaaLu snau'kat 'short-haired (of animal)' 42) njavgat 'smooth (of hair)' < ON snøggr 'short-haired; swift' (> Swe njugg).

= SaaT ńävgsta 'to streak'.

The forms ruotnat (39) and especially luovvat (40) are not the most commonly used forms derived from these stems. The more common forms are ruonas (mod. ruoná 'green') and luovas 'easy to milk', which are phonologically more exact cognates to the loanword origin. These forms also have the widest distribution in Saami (Álgu). This variation is of the same kind as can be seen in the Germanic and Scandinavian loanwords in the Finnic languages, although in Saami the -as forms are more common than -at forms. In the Finnic branch, the distribution is the other way round. Regarding luovvat, it is noteworthy that this is an independent loanword from the same word as Finnish lauha, lauhkea (example 11). This emphasizes the fact that the loanwords have been adapted by the same means in both the Finnic and Saami branches.

The forms snávgat (41) and njavgat (42) belong to the same word group, although Lagercrantz (1939: 542) does not provide the exact origin from which njavgat would have been borrowed. Another possibility is that njavgat is a contamination of snávgat and njuvgat. However, the Ter Saami verb ńâvgsta 'to streak' seems to be a cognate of njavgat. It is the most eastern 
Adaptation of loanwords of the suffix type *-eTA in Finnish and Saami

example, and it suggests that the form njavgat is the oldest of these forms. The crucial feature of these words (41-42) is that they all have been formed with the adjective suffix ${ }^{*}-e T A$ in Saami.

This word group needs to be investigated more closely in order to understand the relationships between the forms, and one must remember that the occurrence of the consonant cluster $s n$-is not necessarily the mark of a young loanword (cf. e. g. snuolga 'snot' < PFU *nolki 'id'). One must keep in mind that the initial consonant cluster $s n$-is much more common in western than eastern Saami languages. Thus, we may treat snávgat and njavgat as alloforms, although they show a difference in the first vowel as well.

Finnish loanwords

43) livkat 'quick' < Finnish or Karelian, cf. Fi liukas 'slippery; quick', Kar liukie, liykie 'gentle (slope); slippery; mild; talkative'. - New etymology. = SaaLu liuhkêtit 'go quickly by'; SaaIn livked 'teem'; SaaSk leu'kked 'twinkle (star), wink (eye)'; SaaKld ı̈̈̄̄e $\delta$ 'id.' (Álgu).

44) girkat 'bright (of eyes)' < Fi kirkas 'bright' (SSA 1: 370).

$=$ SaaIn kirkkad 'bright'.

45) suivat 'boring, dull' < Finnish, cf. Fi suivautua 'get bored; get mad' (Álgu). No cognates in other Saami languages.

The Finnish loanwords ending in -as (43-44) in Saami seem to be treated the same way as Germanic and Scandinavian loanwords (37-42). The reason for this is probably analogy, whereby all phonologically similar endings are assigned to the same suffix type. A more complicated loanword is suivat (example 45) which may have been borrowed as a derived verb, suivastuvvat 'be bored; feel dull', from the Finnish suivautua 'get bored; get mad'. Thus, the form suivat may be a domestic derivation from the verb, especially as there does not seem to be a form ${ }^{* *}$ suivea attested in Finnish. In 4.1.2., I presented two adjectives in North Saami that may be derived from verbs. Another possible example can be seen here in 45 . It is possible that the suffix has had not only a denominal but also a deverbal function in Saami.

Based on Aikio's (2007) observations, I have treated the Finnic *-eTA loanwords in North Saami under the heading "etymological nativization". However, the same analogical pattern can also be seen with Germanic, Scandinavian and Finnish loanwords ending in -as (43-44). Thus, it is perhaps unnecessary to separate etymological nativization from analogical adaptation. 


\subsection{Affixation}

Affixation falls somewhere between regular derivation and morphological adaptation. The suffix is added to the borrowed stem, but in the recipient language the stem itself cannot occur alone; it occurs only as derivation. Some loanwords were adjectives in the donor language as well. In the borrowing process, however, the words gained an adjective suffix, probably to emphasize their adjectival function. This is not part of derivation in the sense that there would be a base form to derive from, nor does the suffix change the word class of the original word. Aronoff and Fudeman (2005) call this affixation, and this is the term I use here. Another term could be pseudo-affixation (McQueen \& Cutler 1998), which emphasizes the nonword stem and the role of analogy in the loanword adaptation process.

North Saami

46) roaffat 'coarse' < Scand cf. Swe grov 'id.' (Âlgu).

No cognates.

47) njuvgat 'very short-haired' < Scand cf. Swe njugg < PScand. snøggr (Bergsland 1964: 145).

= SaaLu njuu'kat 'short and smooth-haired'; SaaIn njuvgâd 'smoothhaired'.

48) riektat 'which can be cut straight through with the grain' < PScand ${ }^{*}$ reht- (> Swe rätt) (Álgu).

Wide distribution in Saami languages.

Affixation seems to be a typical way for Saami to nativize recent Scandinavian loanwords whose second syllables have disappeared. The North Saami njuvgat (47) has either been borrowed from Proto-Scandinavian or, as the first-syllable vowel $u$ suggests, from Swedish. If it is from Swedish, then we could say that the form was produced by affixation, by adding a suffix to the Swedish stem. The same also concerns the word roaffat (46). Both njuvgat and roaffat have a rather restricted distribution, which suggests that the loanwords are more recent than Proto-Scandinavian. Either the suffix has been added by affixation or this phenomenon is intertwined with analogical adaptation. Namely, it is possible that, due to the long contacts between Scandinavian and Saami, some loanwords acquired after the Proto-Scandinavian phase have also been adapted to the -at adjective type. 
The words snávgat, njavgat, and njuvgat are borrowings from the same Scandinavian word group. They have probably been borrowed at different periods, or they are result of internal variation. Nevertheless, they represent a word group that varies formally but not much semantically. The study of expressive and sound-symbolic vocabulary and its variation mechanisms in Saami is almost absent (however, see Aikio 2007). It is therefore impossible, in this article, to answer the question, of whether the forms snávgat, njavgat and njuvgat are separate loanwords or internal constructions based on correlates or model-word parallels.

\section{Conclusions}

\section{I. Semantics of the loanwords}

R. M. W. Dixon (2004) suggests that all languages have some kind of a category of adjectives, and divides adjectives into the following semantic categories: dimension, age, value, colour, physical properties, human propensities, speed, difficulty, similarity, qualification, quantification, and position. Of this list, he suggests that the four first are universally adjectives.

The Finnish $-e A$ adjectives denote particularly physical properties and human propensities. A large amount of the adjectives have an inherent value; mostly negative, but sometimes also positive. Usually the positive affect is used in words denoting speed, or sometimes human propensities. Adjectives denoting physical properties tend to be neutral or negative. If we compare the borrowed $-e A$ adjectives' semantic properties to those of all $-e A$ adjectives in Finnish, the most notable difference that only two loanwords, lakea 'even, open' and laakea 'even, open, shallow' refer to dimension and only one loanword refers to a human propensity (apea 'depressed, unhappy; rueful'). The other loanwords denote mainly physical properties.

The -at adjectives in North Saami also mostly denote physical properties and human propensities. However, the number of colour terms is striking. Of the approximately 110 at-adjectives, over 10 are more or less colour terms. Thus, it seems that -at has a function especially in forming colour terms. Among these colour terms there are both native and borrowed words. A large number of loanwords in the North Saami suffix type -at refer to physical properties (15 of 34 loanwords). The human propensities group includes six loanwords (e.g. roahkkat 'brave'). All of these loans are from Proto-Finnic or Finnish. 


\subsection{The age and type of loanwords}

The oldest loanwords among the Finnish and Saami ${ }^{\star}-e T A$ adjectives are Proto-Baltic and Proto-Aryan. Interestingly, these old loanwords have been taken into the ${ }^{*}-e T A$ adjective type by means of derivation. The youngest loanwords in Finnish come from Russian and Swedish. The Russian loanwords have been assigned to the *-eTA type through morphophonological adaptation. This includes phonological adaptation and structural reinterpretation, which has given the borrowed nouns an adjective function. The Swedish loanword pramea 'handsome; pretentious' has been assigned by means of regular derivation. According to literary texts, it seems rather young. In literature, it has occurred since the 18th century (NSES 2004: 954) and thus strengthens the assumption that the suffix $-e A$ has been productive until recently. Nowadays its productivity has shifted toward model-word derivation and has produced such words as pähee 'cool, neat', kähee 'id', etc. Additionally, the word kolea (colloquially kolee) 'cool, chilling' has gained a new meaning, 'cool, nice', probably based on the polysemy of the English word cool. All in all, the methods producing ${ }^{*}-e T A$ derivatives are more related to the change in word-internal structure than a purely agglutinative method.

North Saami has gained its latest loanwords from Finnish, and probably also from Swedish. New loanwords are assigned to the language by means of morphological adaptation. North Saami has adapted the Finnish words by means of etymological nativization. Thus, the loanwords look surprisingly similar to the old common PFS words. The same system has been used with late Scandinavian loanwords: the long and intensive contacts, as well as bilingualism, have made it possible to use the same adaptation method for both old and new Scandinavian loanwords.

The majority of the loanwords in current Finnish and North Saami data are Germanic and Scandinavian. It is noteworthy that there are no loanwords that would occur in form * ${ }^{*}$ TA both in Finnic and Saami, although they do have eleven common ${ }^{*}-e T A$ adjectives (e.g. Fi virkeä 'bright, alert' SaaN fargat 'quick, agile') ${ }^{12}$. Some of the loanwords presented in this data exist both in Finnish and in Saami, but they are not ${ }^{*}-e T A$ derivations in both. This suggests that the ${ }^{\star}-e T A$-adjectives were derived more or less independently, probably after the Proto-Finno-Saamic phase.

Only one loanword in this data is Slavic (Russian), and it has been assigned in Finnish. In any event, it is not very common to assume Russian 
loanwords in North Saami. The data from eastern Saami languages might reveal other results. We may assume that in Finnic, the suffix ${ }^{*}-e T A$ has been used especially for adapting Germanic and Scandinavian loanwords, rather than Slavic loanwords. From the data, we can also see that Finnish and North Saami have used the same patterns when adapting Germanic and Scandinavian loanwords in their adjective systems. They have even used the same suffix. Both languages have also made independent derivatives from the borrowed stems, and thus we may assume that the suffix *-eTA continued to be productive even after the common Finno-Saamic protolanguage. In fact, its productivity may have actually increased after PFS, as no common PFS loanwords exist in this data.

The results here for the Finno-Saamic data are preliminary because there are plausibly many etymologies yet to be found and the data consists of only one formal type. In this article, I have worked with comparative datings. However, in section 2.2., I have presented the absolute dates of e.g. Finnic and Saami contacts with Proto-Germanic, and here I try to compare the loanword data with the absolute dating. The dates are in the form "no earlier than" and "no later than". The first dating concerns all the loanwords for which we know the source, or the language stage the loanword has come from. The last dating is for estimating such loanwords that are borrowed from contemporary languages and occur in some literature (as shown in examples from Finnish). The languages from which the words are borrowed are mostly Proto-Germanic and Proto-Scandinavian. Based on loanword study, we may give a precautious estimate that the Finnic suffix ${ }^{*}-e \delta a$ has been at its most productive state in the Iron Age, during the contacts with the Proto-Germans and Proto-Scandinavians (Aikio 2006: 42). The ${ }^{*}-e T A$ type, at least, has been popular for assigning Proto-Germanic and ProtoScandinavian loanwords. Some loanwords have also been adapted to the formal type ${ }^{*}-e \delta A$ later on, but these borrowings have been scarce.

As presented earlier, the category of adjectives in Proto-Saami has undergone morphological developments whereby the attributive form has become marked. This means that new words have to be adapted to some existing adjective category, and at least some Germanic and Scandinavian loanwords have been adapted to the formal type PS *-ete. . This same suffix has also been easy to use for loanwords from Proto-Finnic and Finnish.

The suffix * eTA has had a significant role, especially in nativizing Germanic loanwords to the both Finnic and Saami adjective systems. The nativization of Germanic loanwords to Finnic and Saami has been surpris- 
ingly similar, and thus one could assume that the suffix was quite widely used around the time when the Finno-Saamic protolanguage started to disintegrate. However, according to the data, the common loanwords for Saami and Finnic were not borrowed as ${ }^{*}-e T A$ derivations. Instead, the ${ }^{*}$-eTA derivations seem to have been formed later, after borrowing. We might suspect that the ${ }^{*}-e T A$ suffix was not productive or an important suffix in loanword adaptation in the common Finno-Saamic protolanguage, but its importance increased after the languages had separated.

Haspelmath (2009: 42) suggests that if a large number of loanwords have come from a single donor language, there is less need for adaptation. I would rather say that if one word class, e. g. adjectives, gains a large amount of loanwords from a single donor language, there are two options for how to treat these words: either to adapt them to the existing adjective inflection type or adopt a new inflection type along with the loanwords.

\subsection{The productivity of $*_{\text {-eTA }}$}

Germanic and Proto-Scandinavian loanwords have come to the suffix type *-eTA through derivation and adaptation. It seems that the regular derivations have been made either at the same time as the loanwords have been adapted or later. Thus, we may assume that the derivative suffix must be productive at some level in order to receive loanwords by morphological adaptation as well. An exception to this assumption is the Russian loanword apea in Finnish. It has been assigned to language by phonological adaptation, and due to the ending similar to the ${ }^{*}-e T A$ formations it has been reanalysed as an ${ }^{*}-e T A$ adjective, even though in the donor language the word is a noun.

From the data, we can see that the loanwords have not been assigned to the suffix type *-eTA only at the stages of the protolanguages but also, or even especially, later on. In North Saami, the suffix type -at still seems to be productive enough to assign Finnish -eA loanwords to the North Saami -at suffix type. Finnish has also assigned a rather new loanword to the *-eTA type, pramea 'handsome; pretentious', and even by means of regular derivation.

Morphological adaptation uses the models in the language, and for the speaker, ${ }^{\star}$-eTA words seem to be rather a derivative type than a stem type. This means that the suffix can be replaced with another one and variation parallels of the type ${ }^{*}-e T A,{ }^{*}-k e T A,{ }^{*}-k k V$ and in some cases ${ }^{*}-j a(s)$ (as huojas, huokea, laaja, lakea, laakea) have been used as models of adaptation. 
According to the loanword material presented in section 4, the derivative type must accept new derivations in order to accept morphological adaptations. Etymological nativization may be the exception, as there do not seem to be words derived from Finnish loanwords.

In light of what we have found regarding the loanwords assigned to Finnish and Saami, I believe that loanword study may have potential for the study of suffixal productivity in languages that do not have a long written history. It also may give us information on how word-form adaptation affects the productivity of a suffix. In this case, the data sample was too small to make such estimates, but with a larger amount of data and more suffixes, we could find answers regarding the effects of word-form adaptation on suffixal productivity.

Ilona Rauhala Department of Finnish, Finno-Ugrian and Scandinavian Studies P.O. Box 24, FI-00014 University of Helsinki <ilona.rauhala@helsinki.fi>

\section{Notes}

1. Based on a poster presented at the conference Synchrony and Diachrony: Variation and Change in Language History, Oxford in March 2012. My warmest thanks to the Department of Finno-Ugrian and Scandinavian Studies of the University of Helsinki and to the Philological Society for funding my presentation and travel to the conference. In addition, I wish to thank the Finnish Cultural Foundation for funding my studies in 2011-2012.

2. This term is used by Haspelmath (2009: 42).

3. Osmo Nikkiläs (1981) Germanic etymologies for ripeä, rapea, nopea 'swift' and vikeä have not been widely accepted in etymological dictionaries. I have therefore left them out of this article. The word näpeä is, in my opinion, probably derived from näppi 'finger', and is thus not included in this article, although it does require a closer look, e. g. in the case of homonymy.

4. The suggested cognates in Samoyedic (Janhunen 1981) do not have the common suffix * -TA (Rauhala 2011a: 77).

5. There are about 20 common Uralic adjectives, according to Sammallahti (1988: 536-554).

6. Interestingly, VISK (ibid.) adds the word vaalea 'light (of colour)' to the list of opaque formations (in the list called "non-derivation"). The short vowel form valkea 'white' has apparently been left out as a correlate in the synchronic description, although the form ${ }^{* *}$ vaalkea would be impossible to form due to phonotactic rules in the language. This means that the ${ }^{*}-k e T A$ alloform would be valkea even if it were formed by the basis of vaalea.

7. The word hopea is also of Germanic origin (Kallio 2000: 87). 
8. The Finno-Saamic protolanguage reconstruction ${ }^{{ }^{\prime}}$ sope $\delta a$ shows the irregular (?) form suohpe in $\mathrm{SaLu}$, where the form * suohpat would be expected.

9. This is not actually a loanword. It has cognates in Mordvin and Mari and no loanword etymology (SSA 1: 237-8).

10. The word sáhppi 'bladder' has cognates widely in the Uralic languages, e. g. Finnish sappi 'bladder' and Hungarian epe 'id.' (SSA 3: 156-157).

11. For more on substitution rules in native words and loanwords see Aikio 2007.

12. Unless the Germanic etymology for Finno-Saamic *vike- (Finn. vikeä, vikevä, SaaN vahkat) presented by Nikkilä (1981: 75-76) is correct. This etymology has been discarded both by Sammallahti (1998: 124) and by SSA (3:447).

\section{Abbreviations and symbols}

\section{Languages and dialects}

$\begin{array}{llll}\text { Eng } & \text { English } & \text { PGerm } & \text { Proto-Germanic } \\ \text { Est } & \text { Estonian } & \text { PreGerm } & \text { Pre-Proto-Germanic } \\ \text { Fi } & \text { Finnish } & \text { PS } & \text { Proto-Saami } \\ \text { Germ } & \text { German } & \text { PScand } & \text { Proto-Scandinavian } \\ \text { Icel } & \text { Icelandic } & \text { PU } & \text { Proto-Uralic } \\ \text { Ing } & \text { Ingrian } & \text { Rus } & \text { Russian } \\ \text { Kar } & \text { Karelian } & \text { SaaIn } & \text { Inari Saami } \\ \text { Ko } & \text { Komi } & \text { SaaKld } & \text { Kildin Saami } \\ \text { Lit } & \text { Lithuanian } & \text { SaaLu } & \text { Lule Saami } \\ \text { Liv } & \text { Livonian } & \text { SaaN } & \text { North Saami } \\ \text { Lud } & \text { Lude } & \text { SaaS } & \text { South Saami } \\ \text { Nor } & \text { Norwegian } & \text { SaaSk } & \text { Skolt Saami } \\ \text { OHG } & \text { Old High German } & \text { SaaTe } & \text { Ter Saami } \\ \text { ON } & \text { Old Norse } & \text { Scand } & \text { Scandinavian } \\ \text { PBalt } & \text { Proto-Baltic } & \text { Swe } & \text { Swedish } \\ \text { PFi } & \text { Proto-Finnic } & \text { Vot } & \text { Votyan } \\ \text { PFP } & \text { Proto-Finno-Permic } & \text { Vep } & \text { Veps } \\ \text { PFS } & \text { Proto-Finno-Saamic } & \text { VepN } & \text { North dialect of Veps } \\ \text { PFU } & \text { Proto-Finno-Ugric } & & \end{array}$

\section{Grammatical terms and symbols}

$\begin{array}{llll}\text { adj. } & \text { adjective } & \text { part. } & \text { partitive } \\ \text { inf. } & \text { infinitive } & \text { perf. } & \text { perfect } \\ \text { mod. } & \text { modifier } & \text { part. } & \text { participle } \\ \text { n. } & \text { noun } & \star & \text { reconstruction } \\ \text { nom. } & \text { nominative } & * * & \text { non-existing form }\end{array}$




\section{Adaptation of loanwords of the suffix type *-eTA in Finnish and Saami}

\section{References}

Aikhenvald, Alexandra Y. 2007: Typological distinctions in word-formation. - Timothy Shopen (ed.): Language typology and Syntactic Description, volume III: Grammatical categories and the Lexicon. Second edition. Cambridge: Cambridge University Press. 1-65.

Aikio, ANTE 2006: On Germanic-Saami contacts and Saami prehistory. - Journal de la Société Finno-Ougrienne 91: 9-55.

- 2007: Etymological nativization of loanwords. A case study of Saami and Finnish. - Ida Toivonen \& Diane Carlita Nelson (eds): Saami Linguistics. Current Issues in Linguistic Theory, 288. Amsterdam: John Benjamin Publishing Company. 17-52.

- 2009: The Saami loanwords in Finnish and Karelian. Academic dissertation, the Faculty of Humanities of the University of Oulu. <http://cc.oulu.fi/ anaikio/slw.pdf > 8.1.2014.

Aronoff, Mark \& Fudeman, Kirsten 2005: What is Morphology? Fundamentals of Linguistics. Oxford: Blackwell Publishing.

Aronoff, Mark \& Anshen, Frank 1998: Morphology and the Lexicon. - Andrew Spencer \& Arnold M. Zwicky (eds): The Handbook of Morphology. Oxford: Blackwell Publishers. 237-247.

Bartens, Raija 2000: Permiläisten kielten rakenne ja kehitys. Mémoires de la société Finno-Ougrienne 238. Helsinki: Société Finno-Ougrienne.

Bauer, Laurie 2001: Morphological Productivity. Cambridge Studies in Linguistics. Cambridge: Cambridge University Press.

BEKE, ÖDön 1911: Czeremisz nyelvtan. Finnugor Füzetek, 16. Budapest: Magyar Tudományos Akadémia.

Bentlin, Mikкo 2008: Niederdeutsch-finnische Sprachkontakte: Der lexikalische Einfluß des Niederdeutschen auf die finnische Sprache während des Mittelalters und der frühen Neuzeit. Mémoires de la société Finno-Ougrienne 256. Helsinki: Société FinnoOugrienne.

Bergsland, KNUt 1964: Suomen soihtu saamen valossa. - Virittäjä 68: 144-147.

Bybee, JoAn L. 1985: Morphology. A study of the relation between meaning and form. Typological Studies in Language 9. Amsterdam - Philadelphia: John Benjamins Publishing Company.

CAmpbell, Lyle 2004: Historical Linguistics: an Introduction. Second edition. Edinburgh: Edinburgh University Press.

Dixon, R. M. W. 2004: Adjective Classes in Typological Perspective. - R. M. W. Dixon \& Alexandra Y. Aikhenvald (eds): Adjectives and Adverbs. Cambridge: Cambridge University Press. 1-48.

FRIIS, J. A. 1887: Ordbog over det lappiske sprog: med latinsk og norsk forklaring: samt en oversigt over sprogets grammatik. Christiania.

HaKUlinen, LAURI 1979: Suomen kielen rakenne ja kehitys. Neljäs, korjattu ja lisätty painos. Helsinki: Otava.

Hallap, Valmen, 1983: Eesti ja sugulaskeelte adjektiivitüüpe. - Keel ja kirjandus 26: 422-432.

Haugen, E. 1953: The Norwegian Language in America. A Study in Bilingual Behavior. Philadelphia. 
HeLlQuist, ElOF 1922: Svensk etymologisk ordbok. Lund: C. W. K. Gleerups förlag. Hock, Hans Henrich \& Joseph, BRIAN D, 1996: Language History, Language Change, and Language Relationship. Trends in Linguistics, Studies and Monographs 93. Berlin - New York: Mouton de Gruyter.

Haspelmath, Martin 2009: Lexical borrowing: Concepts and issues. - Martin Haspelmath \& Uri Tadmor (eds): Loanwords in the World's Languages: A Comparative Handbook. Berlin: Mouton de Gruyter. 35-54.

HÄKKINEN, KAISA 1997: Mistä sanat tulevat? - Suomalaista etymologiaa. 2nd edition. First edition 1990. Tietolipas 117. Helsinki: Suomalaisen Kirjallisuuden Seura.

ItKonen, Terho, 1982: Laaja, lavea, lakea ja laakea. Lisiä suomen $k j$-sanojen vaiheisiin. - Virittäjä 89: 121-139.

JanhUnen, JuHa 1981: Uralilaisen kantakielen sanastosta. - Journal de la Société FinnoOugrienne 77: 219-271.

- 1982: On the structure of Proto-Uralic. - Finnisch-Ugrische Forschungen 44: 23-42.

JARVA, VeSA 2003: Venäläisperäisyys ja ekspressiivisyys suomen murteiden sanastossa. Jyväskylä Studies in Humanities 198. Jyväskylä: Jyväskylän yliopisto.

Kallio, Petri, 200o: Posti's Superstrate Theory at the Threshold of a New Millennium. - Johanna Laakso (ed.): Facing Finnic: Some Challenges to Historical and Contact Linguistics. Castrenianumin toimitteita 59. Helsinki: Suomalais-Ugrilainen Seura.

KoIvisto, Vesa 2013: Suomen sanojen rakenne. Helsinki: Suomalaisen Kirjallisuuden Seura.

KoIvUlehto, Jorma 1999: Varhaiset indoeurooppalaiskontaktit: aika ja paikka lainasanojen valossa. - Paul Fogelberg (ed.): Pohjan poluilla - Suomalaisten juuret nykytutkimuksen mukaan. Bidrag till kännedom av Finlands natur och folk 153. Helsinki: Societas Scientiarum Fennica. 207-236.

- 2001: Etymologie und lehnwortforschung, ein Überblick um 200o. - FinnischUgrische Forschungen 56: 42-78.

Korhonen, Miкко 1981: Johdatus lapin kielen historiaan. Helsinki: Suomalaisen Kirjallisuuden Seura.

Koski, MaUno 1982: Suomen johto-opin morfologiaa. Fennistica 4. Turku: Åbo Akademi. Kroonen, GuUs 2013: Etymological Dictionary of Proto-Germanic. Leiden - Boston: Brill.

Kulonen, Ulla-Maija 2006: Eläimet ja affekti - etymologisia huomioita. - Virittäjä 110: $322-335$.

LaANeSt, Arvo 1982: Einführung in die ostseefinnischen Sprachen. Hamburg: Helmut Buske Verlag.

Lagercrantz, Eliel 1939: Lappischer Wortschatz I-II. Lexica Societatis Fenno-Ugricae 6. Helsinki: Suomalais-Ugrilainen Seura.

Läglos 1-3 = A. D. Kylstra, SirkKa-LiIsa Hahmo, Tette Hofstra \& Osmo NikKILÄ 1991-2012: Lexikon der älteren germanischen Lehnwörter in den Ostseefinnischen Sprachen. Amsterdam - Atlanta: Rodopi B. V.

Lagman, HerberT 1971: Svensk-estnisk språkkontakt. Studier over estniskans inflytande på de estlandssvenska dialekterna. Acta Universitatis Stockholmiensis. New Series 9. Stockholm.

Lehtiranta, Juhani, 2001: Yhteissaamelainen sanasto. Mémoires de la société FinnoOugrienne 200. 2nd edition. Helsinki: Société Finno-Ougrienne. 


\section{Adaptation of loanwords of the suffix type *-eTA in Finnish and Saami}

Lehtisalo, Toivo 1936: Über die primären Ururalischen Ableitungssuffixe. Mémoires de la société Finno-Ougrienne 72. Helsinki: Société Finno-Ougrienne.

McQueen, James M. \& Cutler, Anne, 1998: Morphology in Word Recognition. - Andrew Spencer \& Arnold M. Zwicky (eds): The Handbook of Morphology. Oxford: Blackwell Publishers. 406-427.

MdWb = PAasonen, HeIKkI 1990-1996: Mordwinisches Wörterbuch I-IV. Lexica Societatis Fenno-Ugricae XXIII. Kotimaisten kielten tutkimuskeskuksen julkaisuja 59. Helsinki: Suomalais-Ugrilainen Seura - Kotimaisten kielten tutkimuskeskus - Venäjän tiedeakatemian kielitieteen laitos.

Nickel, Klaus Peter 1994: Saamisk grammatikk. Davvi Girji o. s.

Nielsen, Konrad 1932/1936/1938: Lappisk ordbok / The Lapp Dictionary 1-3. Oslo: H. Aschehoug \& Co.

NiккıLÄ, Osmo 1981: Germaanisperäisiä 'reippaita' sanoja itämerensuomessa. - Sananjalka 23: 63-82.

- 1993: Suomen sanojen alkuperä. - Ural-Altaische Jahrbücher Neue Folge 12: 279-284.

- 1998: Nopea -> nopsa, selkeä -> selvä: Suffiksinvaihto ja suomen sanojen etymologiointi. - Urho Määttä \& Klaus Laalo (eds): Kirjoituksia muoto- ja merkitysopista. Folia Fennistica \& Linguistica 21. Tampere: Tampereen yliopiston suomen kielen ja yleisen kielitieteen laitos. 77-101.

NSES = HäKKINEN, KAISA (ed.) 2004: Nykysuomen etymologinen sanakirja. Helsinki: WSOY.

OJAnEN, MuUsa 1985: Adjektiivikategoria venäläis-lyydiläisissä kontakteissa. Lingvistinen interferenssitutkimus. Mémoires de la société Finno-Ougrienne 188. Helsinki: Suomalais-Ugrilainen Seura.

Ojansuu, Heıkкi 1918: Karjala-aunuksen äännehistoria. Suomalaisen Kirjallisuuden Seuran toimituksia 162. Helsinki: Suomalaisen Kirjallisuuden Seura.

Pajunen, Anneli 1998: Pääsanaluokkien eriytymättömyydestä uralilaisissa kielissä. Anneli Pajunen (ed.): Kieliopillistumisesta, analogiasta ja typologiasta. Suomi, 185. Helsinki: Suomalaisen Kirjallisuuden Seura. 59-109.

PANTERMÖLler, MARKO 2003: Zur orthographischen Integration von Fremdwörtern im Finnischen. Wiesbaden: Harrassowitz.

PitKÄnen, KAARINA 2008: Suomi kasvitieteen kieleksi. Elias Lönnrot kielen kehittäjänä. Helsinki: Suomalaisen Kirjallisuuden Seura.

Post, MARK, 2008: Adjectives in Thai. - Linguistic Typology 12: 339-381.

Qvigstad, J. 1893: Nordische Lehnwörter im Lappischen. Christiania Videnskabs-Selskabs Forhandlinger for 1893 No. 1. Christiania: Grøndahl \& Søn.

Rauhala, Ilona, 2011a: The History and Variation of the Adjective Suffix *-TA. - Congressus XI Internationalis Fenno-Ugristarum. Piliscsaba 2010, Pars V. Piliscsaba: Reguly Társaság. 77-83.

- 2011b: The terms for black and white and their development in the Uralic languages. Journal de la Société Finno-Ougrienne 93: 267-302.

- 2013: Attribuutin kongruenssi: adjektiivit, demonstratiivit ja *para. - Journal de la Société Finno-Ougrienne 94: 199-221.

Ravila, PAavo 1960: Adjektiiviattribuutin kongruenssin synty suomen kielessä. - Sananjalka 2: 28-35. 
Riessler, Michael 2009: Loanwords in Kildin Saami, a Uralic language of northern Europe. - Martin Haspelmath \& Uri Tadmor (eds): Loanwords in the World's Languages: A Comparative Handbook. Berlin: Mouton De Gruyter.

Rintala, PäIVI 1978: Sananjohdon produktiivisuudesta ja sen rajoituksista. - Auli Hakulinen \& Pentti Leino (eds): Nykysuomen rakenne ja kehitys 1. Tietolipas 93. Helsinki: Suomalaisen Kirjallisuuden Seura. 97-111.

Roos, ARAND 1980: Morfologiska tendenser vid språklig interferens med estniska som bas. - Acta Universitatis Upsaliensis. Studia Uralica et Altaica Upsalensia 12. Uppsala. RÄISÄNEN, ALPO 1978: Kantasanan ja johdoksen suhteesta. - Virittäjä 82: 321-344.

Sammallahti, PeKKa 1998: The Saami languages - an Introduction. Kárášjohka: Davvi girji.

- 1999: Saamen kielen ja saamelaisten alkuperästä. - Paul Fogelberg (ed.): Pohjan poluilla - Suomalaisten juuret nykytutkimuksen mukaan. Bidrag till kännedom av Finlands natur och folk 153. Helsinki: Societas Scientiarum Fennica. 70-90.

- 2001: The Indo-European Loanwords in Saami. - Christian Carpelan, Asko Parpola \& Petteri Koskikallio (eds): Early Contacts between Uralic and Indo-European: Linguistic and Archaeological Considerations. Papers presented at an international symposium held at the Tvärminne Research Station of the University of Helsinki, 8-10 January 1999. Mémoires de la société Finno-Ougrienne 242. Helsinki: Société Finno-Ougrienne. 397-415.

SKES 1-6 = Y. H. Toivonen, Erki Itkonen, Aulis J. Joki \& Reino Peltola (eds) 1955-1978: Suomen kielen etymologinen sanakirja. Lexica Societatis Fenno-Ugricae XII. Helsinki: Suomalais-Ugrilainen Seura.

SSA 1-3 = ERKKI ITKONEN \& Ulla-MAIJA KulONEN (eds): Suomen sanojen alkuperä. Etymologinen sanakirja. Suomalaisen Kirjallisuuden Seuran Toimituksia 556, Kotimaisten kielten tutkimuskeskuksen julkaisuja 62. Helsinki: Suomalaisen Kirjallisuuden Seura - Kotimaisten kielten tutkimuskeskus 1992-200o.

TADMOR, URI 2009: Loanwords in the World's languages: Findings and results. - Martin Haspelmath \& Uri Tadmor (eds): Loanwords in the World's Languages: A Comparative Handbook. Berlin: Mouton de Gruyter.

Thомsen, VILH. 1869: Den gotiske sprogklasses indflydelse på den finske. - En sproghistorisk undersøgelse. København: Den Gyldendalske boghandel.

Tunkelo, E. A. 1913-1918: Suomalais-germaanisten kosketusten alalta. - Journal de la Société Finno-Ougrienne 30: 29.

Uotila, T. E, 1933: Zur Geschichte des Konsonantismus in den permischen Sprachen. Mémoires de la société Finno-Ougrienne 65. Helsinki: Société Finno-Ougrienne.

VISK = Auli Hakulinen, Maria Vilkuna, Rittta Korhonen, Vesa Koivisto, Tarja Rittta Heinonen \& Irja AlHo 2004: Iso suomen kielioppi. Helsinki: Suomalaisen Kirjallisuuden Seura. Online-version. <http://scripta.kotus.fi/visk>. 13.5.2014.

WOLD = MARTIN HASPELMATH \& URI TADMOR (eds) 2009: World Loanword Database. Leipzig: Max Planck Institute for Evolutionary Anthropology.

$<$ http://wold.livingsources.org > 15.1.2014.

$A ́ l g u=$ Sámegielaid etymologaš diehtovuođđu $=$ The etymological database of the Saami Languages [online-database]. Helsinki: Kotimaisten kielten tutkimuskeskus. November 2006. Constantly updated. (Included in collection Etymology.) $<$ http://kaino.kotus.fi/algu/> 14.1.2014. 